\title{
Formation of organic aerosol in the Paris region during the MEGAPOLI summer campaign: evaluation of the volatility-basis-set approach within the CHIMERE model
}

\author{
Q. J. Zhang ${ }^{1,13}$, M. Beekmann ${ }^{1}$, F. Drewnick ${ }^{2}$, F. Freutel ${ }^{2}$, J. Schneider ${ }^{2}$, M. Crippa ${ }^{3}$, A. S. H. Prevot ${ }^{3}$, \\ U. Baltensperger ${ }^{3}$, L. Poulain ${ }^{4}$, A. Wiedensohler ${ }^{4}$, J. Sciare ${ }^{5}$, V. Gros ${ }^{5}$, A. Borbon ${ }^{1}$, A. Colomb ${ }^{1,6}$, V. Michoud ${ }^{1}$, \\ J.-F. Doussin ${ }^{1}$, H. A. C. Denier van der Gon ${ }^{7}$, M. Haeffelin ${ }^{8}$, J.-C. Dupont ${ }^{8}$, G. Siour ${ }^{1,9}$, H. Petetin $^{1,12}$, B. Bessagnet ${ }^{9}$,

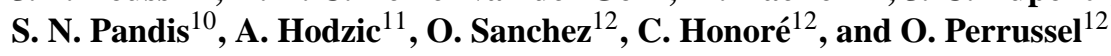 \\ ${ }^{1}$ LISA/IPSL, Laboratoire Interuniversitaire des Systèmes Atmosphériques, UMR7583, CNRS, Université Paris Est Créteil \\ (UPEC) et Université Paris Diderot (UPD), Créteil, France. \\ ${ }^{2}$ Max Planck Institute for Chemistry, Particle Chemistry Department, Mainz, Germany \\ ${ }^{3}$ Laboratory of Atmospheric Chemistry, Paul Scherrer Institute, Villigen, Switzerland \\ ${ }^{4}$ Leibniz Institute for Troposphärenforschung, Leipzig, Germany \\ ${ }^{5}$ Laboratoire des sciences du climat et de l'environnement, IPSL, CEA et l'Université de Versailles, CNRS, \\ Saint-Quentin, France \\ ${ }^{6}$ Laboratoire de Météorologie Physique, Clermont-Ferrand, France \\ ${ }^{7}$ TNO, Dept. Climate, Air and Sustainability, Utrecht, the Netherlands \\ ${ }^{8}$ IPSL, Ecole Polytechnique, INSU/CNRS 1'Université de Versailles, Saint-Quentin,, France \\ ${ }^{9}$ Institut National de l'EnviRonnement industriel et des rISques, Verneuil en Halatte, France \\ ${ }^{10}$ Institut of Chemical Engineering Sciences, Foundation for Research and Technology, Hellas, Patras, Greece \\ ${ }^{11}$ National Center for Atmospheric Research, Boulder, USA \\ ${ }^{12}$ AIRPARIF, Agence de Surveillance de la qualité de l'air, Paris, France \\ ${ }^{13}$ ARIA Technologies, Boulogne-Billancourt, France
}

Correspondence to: Q. J. Zhang (qzhang@aria.fr)

Received: 17 October 2012 - Published in Atmos. Chem. Phys. Discuss.: 15 November 2012

Revised: 6 May 2013 - Accepted: 7 May 2013 - Published: 14 June 2013

\begin{abstract}
Simulations with the chemistry transport model CHIMERE are compared to measurements performed during the MEGAPOLI (Megacities: Emissions, urban, regional and Global Atmospheric POLlution and climate effects, and Integrated tools for assessment and mitigation) summer campaign in the Greater Paris region in July 2009. The volatility-basis-set approach (VBS) is implemented into this model, taking into account the volatility of primary organic aerosol (POA) and the chemical aging of semi-volatile organic species. Organic aerosol is the main focus and is simulated with three different configurations with a modified treatment of POA volatility and modified secondary organic aerosol (SOA) formation schemes. In addition, two types of emission inventories are used as model input in order to test
\end{abstract}

the uncertainty related to the emissions. Predictions of basic meteorological parameters and primary and secondary pollutant concentrations are evaluated, and four pollution regimes are defined according to the air mass origin. Primary pollutants are generally overestimated, while ozone is consistent with observations. Sulfate is generally overestimated, while ammonium and nitrate levels are well simulated with the refined emission data set. As expected, the simulation with non-volatile POA and a single-step SOA formation mechanism largely overestimates POA and underestimates SOA. Simulation of organic aerosol with the VBS approach taking into account the aging of semi-volatile organic compounds (SVOC) shows the best correlation with measurements. High-concentration events observed mostly 
after long-range transport are well reproduced by the model. Depending on the emission inventory used, simulated POA levels are either reasonable or underestimated, while SOA levels tend to be overestimated. Several uncertainties related to the VBS scheme (POA volatility, SOA yields, the aging parameterization), to emission input data, and to simulated $\mathrm{OH}$ levels can be responsible for this behavior. Despite these uncertainties, the implementation of the VBS scheme into the CHIMERE model allowed for much more realistic organic aerosol simulations for Paris during summertime. The advection of SOA from outside Paris is mostly responsible for the highest OA concentration levels. During advection of polluted air masses from northeast (Benelux and Central Europe), simulations indicate high levels of both anthropogenic and biogenic SOA fractions, while biogenic SOA dominates during periods with advection from Southern France and Spain.

\section{Introduction}

Human activities in large urban agglomerations cause large amounts of pollutant emissions, with negative effects on air quality and human health at the local and regional scale (Gurjar et al., 2008; Sicard et al., 2011). Aerosol degrades visibility and may have negative impacts on ecosystems (Molina and Molina, 2004). It also affects climate by changing the radiative balance of the atmosphere (direct and indirect effects, IPCC, 2007). Organic aerosol makes up a large part of fine aerosol $\left(\mathrm{PM}_{2.5}\right)$ (Putaud et al., 2010), but there are still large gaps in our understanding of its formation pathways, and there is considerable uncertainty in its representation in 3-D models (Volkamer et al., 2006; Hallquist et al., 2009; Virtanen et al., 2010).

Models, based on partitioning theory and secondary organic aerosol (SOA) yields obtained from chamber studies performed especially in the 1990s, have largely underestimated ambient SOA (Volkamer et al., 2006). The experimental conditions during these chamber studies may have not correctly represented ambient conditions. The experiment duration was often too short to take into account the ongoing oxidation of semi-volatile organic compounds (SVOC). Important but unrecognized precursors were neglected (Kroll and Seinfeld, 2008; Hallquist et al., 2009). Semi-empirical formulas used for the estimation of vapor pressure and enthalpy of surrogate products may also induce additional uncertainty (Hallquist et al., 2009; Vaden et al., 2010, 2011; Valorso et al., 2011).

In the Paris region, a previous study (Sciare et al., 2010) compared SOA modeled with the regional chemistry transport model (CTM) CHIMERE using a surrogatespecies-based single-step oxidation SOA scheme described in Sect. 3.4.1 (Pun et al., 2006) against observations derived from the "EC-tracer" method (Turpin and Huntzicker, 1995;
Strader et al., 1999; Cabada et al., 2004) at an urban site. The SOA concentrations simulated with this scheme were on average underestimated by a factor of three. Even larger errors were encountered when aged air mass with high SOA levels arrived at the observation site. This scheme was also evaluated by Bessagnet et al. (2009) for Europe and by Hodzic et al. (2009) for Mexico City, a megacity dominated by anthropogenic emissions. Bessagnet et al. (2009) concluded that simulated OA concentrations are systematically underestimated with respect to rural background observations available from the CARBOSOL campaign and EMEP EC/OC campaign measurement data (for year 2003, Simpson et al., 2007). Hodzic et al. (2009) reported an underestimation of a factor of 2-10 for daytime SOA production in Mexico City during the MILAGRO field campaign in March 2006. Recently, a surrogate-species-based SOA formation scheme taking into account POA volatility and SVOC chemical aging was used within the POLYPHEMUS model and applied to the OA formation in the Paris agglomeration (Couvidat et al., 2013).

Since the semi-volatile nature of primary organic aerosol (POA) has been recognized (e.g., Robinson et al., 2007), this feature has started to be taken into account in 3-D models, where POA had generally been considered as non-volatile. According to the partitioning theory (Pankow, 1994; Donahue et al., 2006), the fraction of SVOC present in the aerosol phase is much larger close to emission sources with high OA levels than under ambient conditions, when OA is diluted. Thus, POA emissions constructed from measurements performed at high OA loading (typically ranging from 1000 to $10000 \mu \mathrm{g} \mathrm{m}^{-3}$ ) will result in an overestimation of POA concentrations at ambient $\mathrm{OA}$ levels (typically ranging from 1 to $10 \mu \mathrm{g} \mathrm{m}^{-3}$ ), if the POA volatility is not taken into account. In addition, emissions of organic compounds of intermediate volatility (IVOC, with saturation concentration ranging from $10^{4}$ to $10^{6} \mu \mathrm{g} \mathrm{m}^{-3}$, Dohanue et al., 2006) are often not yet included in current air quality simulations (Robinson et al., 2007; Grieshop et al., 2009, Kukkonen et al., 2012). The gas phase SVOCs and IVOCs undergo multi-step oxidation to become less volatile than their parent SVOC or IVOC and can then condense into the particle phase. This part of additional SOA, named oxidized primary organic aerosol (OPOA), (Robinson et al., 2007) may account for a substantial fraction of SOA (Shrivastava et al., 2008; Murphy and Pandis. 2009; Presto et al., 2009, 2010). These features have been recently formalized and parameterized in a framework named volatility-basis-set (VBS) approach (Donahue et al., 2006; Robinson et al., 2007). Multi-step oxidation of classic SOA precursors, such as aromatic compounds or terpenes, has also been included in this framework (Lane et al., 2008a; Tsimpidi et al., 2010).

The VBS approach has been applied in different models (WRF-Chem, PMCAMx, CHIMERE and EMEP) in order to simulate primary and secondary organic aerosol over the USA (Shrivastava et al., 2008; Murphy and Pandis. 2009), 
Table 1. Description of the three ground-based primary measurement sites during the MEGAPOLI campaigns.

\begin{tabular}{llll}
\hline Site & Location & Type & Comments \\
\hline $\begin{array}{l}\text { LHVP (Laboratoire d'Hygiène } \\
\text { de la Ville de Paris) }\end{array}$ & $\left(2.36^{\circ} \mathrm{E}, 48.30^{\circ} \mathrm{N}\right)$ & urban background site & located in the downtown of Paris \\
$\begin{array}{l}\text { SIRTA (Site Instrumental de } \\
\text { Recherche par Télédétection } \\
\text { Atmosphérique) }\end{array}$ & $\left(2.21^{\circ} \mathrm{E}, 48.71^{\circ} \mathrm{N}\right)$ & suburban background site & $\begin{array}{l}\text { located on the southwestern edge } \\
\text { of the Paris agglomeration, about }\end{array}$ \\
GOLF (GOLF Poudrière) & $\left(2.55^{\circ} \mathrm{E}, 48.93^{\circ} \mathrm{N}\right)$ & suburban background site & $\begin{array}{l}\text { downtown } \\
\text { located on the northeastern edge } \\
\text { of the Paris agglomeration, about } \\
20 \mathrm{~km} \text { from the LHVP site }\end{array}$ \\
\hline
\end{tabular}

over Mexico City (e.g., Hodzic et al., 2010; Tsimpidi et al., 2010) and over Europe (Fountoukis et al., 2011; Bergström et al., 2012). Comparisons between simulated OA components with this approach and those derived from positive matrix factorization (PMF) of aerosol mass spectrometer (AMS) measurements (Lanz et al., 2010; Ulbrich et al., 2009) performed for Mexico City were encouraging (Tsimpidi et al., 2010; Hodzic et al., 2010). In general, simulations using the VBS approach in which evaporation of POA emissions, additional IVOC emissions, and chemical aging of gas phase IVOC and SVOC were taken into account gave better agreement in terms of SOA mass when compared to measurement than simulations using traditional SOA formation schemes. These studies suggest that OPOA produced from oxidation of gas phase IVOC and SVOC might represent a non-negligible fraction of SOA.

In the framework of the European Seventh Framework Program (EU/FP7) project MEGAPOLI (Megacities: Emissions, urban, regional and Global Atmospheric POLlution and climate effects, and Integrated tools for assessment and mitigation) (Baklanov et al., 2008), an intensive measurement campaign was launched in the Greater Paris region in July 2009. The major objective was to provide new experimental data in order to better quantify the origin of the organic aerosol within a megacity and to better understand secondary aerosol formation in an urban plume. Another aim of the campaign was to provide a database for detailed model evaluation. Detailed chemistry measurements for gas and aerosol were made at three ground-based primary measurement sites across the Paris agglomeration along a SWNE axis (Fig. 1): the LHVP (Laboratoire d'Hygiène de la Ville de Paris) site in Paris 13th arrondissement is an urban background site, while the GOLF Poudrière site (denoted as GOLF in the following text) in Livry Gargan and the SIRTA (Site Instrumental de Recherche par Télédétection Atmosphérique) atmospheric research observatory at Ecole Polytechnique in Palaiseau (Haeffelin et al., 2005) are suburban sites on the northeastern and southwestern edge of the agglomeration, respectively. A short description of site characteristics is given in Table 1. The Paris agglomeration is often influenced either by polluted continental air masses advected from northeast or by clean oceanic air masses advected from west or southwest. For each situation, one site was located upwind, within, and downwind of Paris.

In this study, we focus on the evaluation of the CHIMERE model performance against the observations during the summer campaign 2009, in particular for organic aerosol and for different aerosol schemes and the VBS framework. A model simulation for the MEGAPOLI campaign has previously been compared with mobile ground-based lidar measurements around the Paris agglomeration from which $\mathrm{PM}_{10}$ values have been derived (Royer et al., 2011). Wet $\mathrm{PM}_{10}$ vertically integrated between the ground and $1 \mathrm{~km}$ above ground level from lidar and CHIMERE results have been compared and have shown similar results with a root-mean-square error (and mean absolute percentage error) of about $5 \mathrm{mg} \mathrm{m}^{-2}$ (22\%). With respect to earlier studies evaluating the VBS scheme within chemistry transport models cited above, this work focuses on a European megacity which is subject both to local emissions of primary organic aerosol and to advection of secondary organic aerosol during well-defined transport regimes. In Sect. 2.1, a short description of the measurements during the MEGAPOLI summer campaign is given. Different meteorological and transport regimes are discussed in Sect. 2.2. In Sect. 3, the reference model configuration and simulation set-up using the VBS approach to model POA and SOA are introduced; different alternative model scenarios using different emission inventories and model configurations with different OA schemes are presented. A general evaluation of model performance is presented in Sect. 4, both for the ground-based meteorological observations and chemical measurements. A specific evaluation of primary and secondary OA simulations is performed in Sect. 4.5.

\section{Measurements and pollution regimes during the MEGAPOLI summer campaign}

\subsection{Measurements}

The meteorological parameters such as $2 \mathrm{~m}$ height temperature and relative humidity, wind speed and direction at $10 \mathrm{~m}$ 


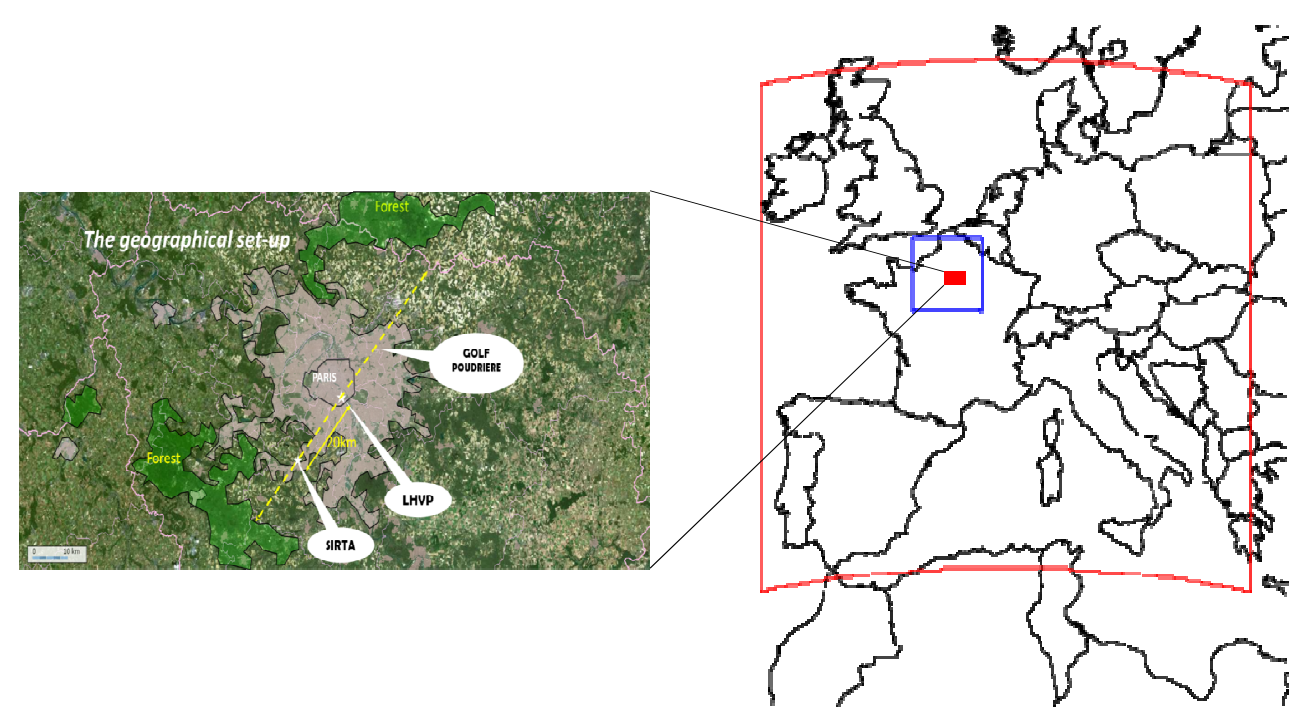

Fig. 1. Location of the urban and the two suburban sites (left) and the simulation domain (right); the European CONT3 domain (in red), the nested Northern France MEG3 domain (in blue), and the Greater Paris region (indicated by a red rectangle). The yellow dashed line corresponds to the major SW and NE wind directions prevailing in the region.

Table 2. Meteorological and chemical instruments deployed at the three main measurement sites.

\begin{tabular}{llll}
\hline $\begin{array}{l}\text { Meteorology/gas/aerosol } \\
\text { Temperature/wind }\end{array}$ & $\begin{array}{l}\text { Instrument type } \\
\text { Meteorological station }\end{array}$ & Time resolution & $\begin{array}{l}\text { Site } \\
\text { SIRTA }\end{array}$ \\
\cline { 1 - 2 } $\begin{array}{l}\text { PBL }^{1} \text { height (lidar derived with } \\
\text { scattering intensity) }\end{array}$ & Elastic backscatter lidar & & \\
\hline $\mathrm{NO}_{\mathrm{x}}$ & Chemiluminescence & $1 \mathrm{~min}$ & LHVP, GOLF, SIRTA \\
$\mathrm{O}_{3}$ & UV photometric analyzer & $1-5 \mathrm{~min}$ & LHVP, GOLF, SIRTA, \\
$\mathrm{BC}$ & MAAP & $1-5 \mathrm{~min}$ & LHVP, GOLF \\
$\begin{array}{l}\text { Non-refractory PM } \\
\text { Nitrate, sulfate, ammonium and } \\
\text { organic aerosol }\end{array}$ & Aethalometer & $5 \mathrm{~min}$ & SIRTA \\
\hline
\end{tabular}

\footnotetext{
${ }^{1}$ PBL: planetary boundary layer

2 MAAP: multi-angle absorption photometer;

${ }^{3}$ HR-ToF-AMS: high-resolution time-of-flight AMS

${ }^{4}$ C-ToF-AMS: compact ToF AMS.
}

height were provided by the SIRTA observatory. Table 2 lists information about gas and aerosol measurements deployed at the three main measurement sites, which are used in this work for model evaluation. In the agglomeration, $\mathrm{NO}_{\mathrm{x}}$ and black carbon (BC) are considered as urban or, more precisely, as mainly traffic-related emission tracers. Ozone is evaluated as a tracer of past photochemical activity in incoming air masses. Inorganic and organic aerosol measurements are sampled by several instruments. Here we only use the measurements with AMS (DeCarlo et al., 2006; Drewnick et al., 2005).

Freutel et al. (2013) have evaluated the AMS measurements in terms of total mass measurement (including BC measurements from a multi-angle absorption photometer
(MAAP)) using a $\mathrm{PM}_{1}$ TEOM-FDMS at LHVP and GOLF and aerosol size distribution measurement from a SMPS at SIRTA, and found good agreement. The fraction of the total mass covered by the AMS measurements is about 0.9 for both LHVP and the GOLF site. The overall uncertainty of AMS measurements of different PM components is estimated as $30 \%$. Source apportionment from PMF analysis of AMS measurements was applied to study the origins and the potential sources of OA (Freutel et al., 2013; Crippa et al., 2013a, for the SIRTA site). In this paper, focusing on the urban LHVP site, only the solution from Freutel et al. (2013) is used. Two factors were attributed to hydrocarbon-like organic aerosol (HOA) and oxygenated organic aerosol (OOA). Their concentrations were previously found to be strongly 

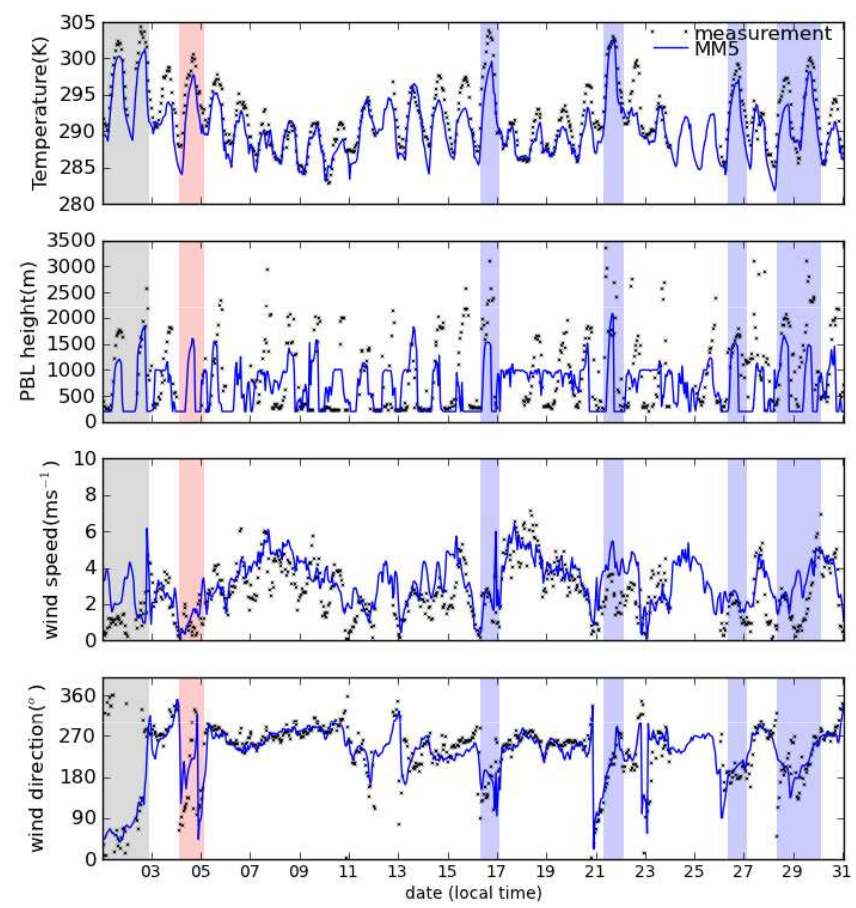

Fig. 2. Comparison of simulated (blue lines) and observed (black dots) temperature, boundary layer (PBL) height, wind speed, and wind direction at SIRTA; the grey bar represents the period R1 during a continental regime; the red bar the $\mathrm{R} 2$ period during the local regime; the blue bar the $\mathrm{R} 3$ regime with southerly advection; and the white background indicates the Atlantic regime (R4).

linked to POA and SOA by comparing their spectra with known sources and their time series with other tracers (U1brich et al., 2009). A third important factor identified was related to cooking activities (about $36 \%$ of total OA) only at LHVP (Freutel et al., 2013). As cooking emissions are not included in our simulations (Junkle and Liousse, 2008), we rely in this work on the results of HOA from the 3-factor PMF analysis which can be compared to modeled POA produced from predominant traffic emissions.

\subsection{Pollution regimes}

From a combined analysis of meteorology and pollution characteristics, the MEGAPOLI summer campaign can be divided into four periods (Fig. 2) with distinct chemical transport regimes:

- R1: Northeasterly weak winds under anti-cyclonic conditions during two days on 1 and 2 July which led to advection of pollution from Benelux (Belgium, the Netherlands, and Luxembourg) and Rhine-Ruhr region (Germany) to the Paris agglomeration; high temperature above $305 \mathrm{~K}\left(32^{\circ} \mathrm{C}\right)$.
- R2: Weak winds with variable direction and high temperature above $300 \mathrm{~K}\left(27^{\circ} \mathrm{C}\right)$ on 4 July, favoring local accumulation of pollutants.

- R3: Mainly southerly winds, but sometimes weak and instable, rather high temperatures around $300 \mathrm{~K}$ on 16 , 21, 26, and 28-29 July.

- R4: Westerly to southwesterly wind-advecting clean marine air masses, lower temperatures than during the other regimes, mostly cloudy with rarely rainy conditions; weak rotating wind on 11 July, relatively higher wind speed from $2-6 \mathrm{~m} \mathrm{~s}^{-1}$ for the rest of the period.

During this campaign, no important precipitation event occurred in the Ile-de-France region.

\section{Simulations}

\subsection{Model configuration}

In this work, we used the CHIMERE v2008b version (see http://www.lmd.polytechnique.fr/chimere/) (Bessagnet et al., 2009). It is widely used for operational regional air quality forecasts (Honoré et al, 2008) and simulations in Europe (Beekmann and Vautard, 2010; Sciare et al, 2010) and elsewhere (including air quality forecasts in Beijing (Zhang et al., 2012) and simulations in Mexico City (Hodzic et al., 2009, 2010)). CHIMERE is used as the French national tool for air quality forecast (http://www.prevair.org/).

Two nested domains are used for simulations in this study: a continental domain which covers Europe with a resolution of $0.5^{\circ}\left(35-57.5^{\circ} \mathrm{N} ; 10.5^{\circ} \mathrm{W}-22.5^{\circ} \mathrm{E}\right)$ and a regional domain over Northern France with a resolution of $3 \mathrm{~km}$ (Fig. 1). Eight hybrid-sigma vertical layers are used, with the first layer extending from the ground to about $40 \mathrm{~m}$. The model top is at $500 \mathrm{hPa}$. Tropospheric gas phase chemistry is represented using the reduced MELCHIOR chemical mechanism (Lattuati, 1997; Derognat et al., 2003), including 120 reactions and 44 gaseous species. For the simulation of the particulate phase, 8 bins with diameters ranging from 0.04 to 10 micrometers are used. A dry deposition velocity for gases and aerosol is computed by use of a resistance analogy (Wesely, 1989). Wet removal of gases and aerosol in clouds and by precipitation is taken into account (Tsyro, 2002; Loosmore and Cederwall, 2004). The thermodynamic equilibrium of the inorganic species (sulfate, nitrate, ammonium and water) is interpolated from a table precalculated with the ISORROPIA model (Nenes et al., 1998). The thermodynamic equilibrium of evaporation and condensation processes is kinetically controlled by the absorption flux (Seinfeld and Pandis, 2006). SOA schemes such as the method in the standard CHIMERE version with single-step oxidation (denoted here as CSS) and the VBS approach are both used here. They are respectively described in Sects. 3.3 and 3.4. 
POA is considered as non-volatile in a simulation with the standard version. It is also simulated with the VBS approach in which its volatility is taken into account (see details in Sect. 3.3).

Meteorological parameters are input for CHIMERE and are taken from simulations with the PSU/NCAR MM5 model (Dudhia, 1993) for two nested domains with $45 \mathrm{~km}$ (European domain) and $15 \mathrm{~km}$ (Northwest Europe) resolution. In the vertical direction, 23 sigma layers extend up to $100 \mathrm{hPa}$. MM5 is forced by the final analyses from the Global Forecast System (GFS/FNL) operated daily by the American National Centers for Environmental Prediction (NCEP), using the grid nudging (grid FDDA) option implemented within MM5. MM5 often predicts low nighttime PBL height down to $70 \mathrm{~m}$ in urban regions. This is related to the fact that urban canopy and urban heating effects are not taken into account in this model. Therefore, the minimum modeled PBL height is set to $200 \mathrm{~m}$, which is close to the lowest measurements.

CHIMERE simulations use boundary conditions from a monthly climatology of the LMDz-INCA2 and LMDzAERO general circulation model (Hauglustaine et al., 2004). The boundary condition for organic aerosol concentrations over the Atlantic is set to about $0.7 \mu \mathrm{g} \mathrm{m}^{-3}$ according to longterm measurements and climatologic analyses (Seinfeld and Pandis, 2006; Cachier et al., 1986).

\subsection{Emissions}

Two different anthropogenic emission inventories were used in this study. For the reference simulations, anthropogenic gas phase emissions are calculated from EMEP annual totals for the year 2005 with a $50 \mathrm{~km}$ resolution (http://www. ceip.at/emission-data-webdab/), while BC and POA are prescribed from the Laboratoire d'Aérologie (LA) emission inventory also for the year 2005 (Junker and Louisse, 2008) with a $0.25^{\circ}$ resolution. This corresponds to the emission database used in the standard CHIMERE configuration also used for operational national air quality forecast within the PREV'AIR system (Honoré et al., 2008). For the nested simulations, these emissions are downscaled using a land use distribution as described in Bessagnet et al. (2009). In addition, an emission inventory (denoted as MPOLI in the following text) has been developed for both the gas and particulate phases by TNO and Airparif within the MEGAPOLI project, taking into account specific information for the Paris agglomeration (Denier van der Gon et al., 2011). In this inventory, the refined Paris emissions are delivered by Airparif (Airparif, 2010) with a $1 \mathrm{~km}$ resolution and were integrated into a European inventory with $7 \mathrm{~km}$ resolution (Pouliot et al., 2012). POA emissions from the MPOLI inventory are about three times lower in the Paris region than those from the LA one (Fig. S1 in the Supplement), while they are substantially higher in the surroundings. This latter fact is principally due to the inclusion of a strong OM emission source in the agricultural sectors in the MPOLI, but not in the LA inventory. Both of these emissions sets are scaled to hourly emissions, applying temporal profiles provided by IER (Friedrich, 1997). Biogenic emissions are calculated online using data from MEGAN (Model of Emissions of Gases and Aerosols from Nature) and parameterizations by Guenther et al. (2006).

\subsection{Volatility-basis-set approach for primary organic aerosol emissions}

We apply the volatility profiles as presented by Robinson et al. (2007) for each simulated volatility and size of POA and IVOC species. They are classified into 9 bins represented by their saturation concentration $C^{*}$ (Table $\mathrm{S} 1$ in the Supplement), neighboring bins being separated by a factor of 10 in $C^{*}$. The additional gas phase IVOC emissions are set as 1.5 times the value of POA emissions as in earlier modeling studies (Robinson et al., 2007; Shrivastava et al., 2008; Murphy and Pandis, 2009; Hodzic et al., 2010; Tsimpidi et al., 2010). The factor of 1.5 corresponds to the value obtained from previous chamber studies for emission of diesel exhaust (Robinson et al., 2007; Shrivastava et al., 2008). The parameters used to simulate the partitioning of POA emissions, such as the reference saturation concentration $C^{*}$ at $298 \mathrm{~K}$, the enthalpy and emission factors with respect to the traditional non-volatile POA emissions for each class of compounds are presented in Table S1 in the Supplement. Introducing these SVOC and IVOC species into the VBS approach results in 136 new species and 17 chemical reactions to be computed, which roughly doubles the computational time of CHIMERE.

Assuming a maximum $\mathrm{OA}$ ambient concentration of $10 \mu \mathrm{g} \mathrm{m}^{-3}$ in Paris during summertime, IVOC species in the volatility bins between $10^{4}$ and $10^{6} \mu \mathrm{g} \mathrm{m}^{-3}$ are almost totally in the gaseous phase. The particulate phase fraction in the bin for the least volatile $\mathrm{IVOC}_{i}$ bin with $C^{*}=10^{4} \mu \mathrm{g} \mathrm{m}^{-3}$ represents only $0.15 \%$ of the total POA under typical summer conditions $\left(T=298 \mathrm{~K}, \mathrm{OA}=10 \mu \mathrm{g} \mathrm{m}^{-3}\right)$. Therefore, IVOC compounds are considered in the model to be present only in the gas phase in summer. The six less volatile SVOC bins are considered to be semi-volatile and partitioning between gas and particle phases. This reduction of semi-volatile bins and species to be treated results in about $30 \%$ less computational cost.

The emission factors for calculating diesel-exhaust-related POA emissions for both the LA and MPOLI inventories are obtained from laboratory measurements under a low level of dilution with high OA loading (of the order of $1000 \mu \mathrm{g} \mathrm{m}^{-3}$ (Pillot et al., 2009)), similar to that described in Robinson et al. (2007). Under such conditions, about $75 \%$ of SVOC emissions are expected to occur in the particle phase according to the dilution experiments described in Robinson et al. (2007). No correction is applied in this work to account for the missing $25 \%$ not captured in the emission factor measurements, because the correction would be much smaller 
than the uncertainty related to the emission inventory itself (see above for differences between the LA and MPOLI inventories). Diesel exhaust emissions are dominant for POA at least during summer. Thus, POA emissions in the LA and MPOLI inventories are taken as input for the VBS approach, and the emission factor profile from Robinson et al. (2007) for diesel exhaust is applied, like in Shrivastava et al. (2008) and Murphy and Pandis (2009) for the USA. Note that, for Mexico City (Hodzic et al., 2010; Tsimpidi et al., 2010), emission factors for organic aerosol were determined under ambient pollution conditions. In this case, emission factors have been multiplied by a factor of three in order to take into account emitted SVOCs present in the gas phase and not captured in the POA measurements.

In the VBS scheme, the gas phase oxidation of semivolatile POA is taken into account by shifting SVOC and IVOC species successively to bins with lower volatility (Robinson et al., 2007). The reaction rate constant of the SVOC and IVOC reaction with $\mathrm{OH}$ is estimated as $4 \times 10^{-11} \mathrm{~cm}^{-3}$ molecules ${ }^{-1} \mathrm{~s}^{-1}$ (Murphy and Pandis, 2009). Each oxidation reaction increases the species mass by $7.5 \%$ to account for added oxygen (Robinson et al., 2007; Shrivastava et al., 2008). The formation of secondary compounds (OPOA) from oxidized SVOC is again governed by the gas-particle partitioning theory as a function of the $\mathrm{OA}$ mass loading and ambient temperature.

\subsection{SOA in CHIMERE}

Two schemes for SOA formation are used here. One is the single-step oxidation scheme used in the CHIMERE standard version (Pun et al., 2006; Bessagnet et al., 2009; Hodzic et al., 2009); the other is the VBS approach (Lane et al., 2008a).

\subsubsection{Single-step oxidation}

In the single-step oxidation mechanism the formation of SVOC species is parameterized by a single oxidation step, which nevertheless can represent several individual oxidation steps. SVOC species are then considered as chemically inert for the rest of the simulation. As a function of their volatility and preexisting OA, SVOC species undergo gas-particle partitioning to reversibly form SOA. The SVOC yields and volatilities are derived from previous laboratory experiment data for several types of precursors (Pun et al., 2006).

Both anthropogenic and biogenic VOC species can act as SOA precursors. Anthropogenic VOC emissions are distributed into 266 individual VOC species following emission-sector-specific emission profiles given by Passant (2002). These species are aggregated into 9 lumped VOC classes according to the mass molar weight and the reactivity of individual species and VOC class representatives (Middleton et al., 1990). Three of these lumped anthropogenic VOC classes - a class of alkanes from C4 to $\mathrm{C} 13$, a class of benzene, toluene and other mono-substituted aromatics, and a class of tri-methylbenzene and other polysubstituted aromatics - represent SOA precursors. The latter 2 classes are only used for SOA formation, and do not interfere with gas phase chemistry. All classes are oxidized by $\mathrm{OH}$, ozone and $\mathrm{NO}_{3}$ to produce semi-volatile organic compounds. Oxidation of biogenic VOC species as SOA precursors ( $\alpha$-pinene, sabinene, $\beta$-pinene, $\delta^{3}$-carene, limonene, ocimene, myrcene and isoprene; Table S2 in the Supplement) is also taken into account. The SVOC products are presented as surrogate hydrophobic and hydrophilic species, grouped according to their hydrophilic character, i.e., water solubility, acid dissociation and saturation vapor pressure (Bessagnet et al., 2009).

\subsubsection{VBS approach for SOA formation}

SOA (or SVOC) produced from precursors of anthropogenic and biogenic VOC, named ASOA (or anthropogenic SVOC) and BSOA (or biogenic SVOC), respectively, is simulated by using four different volatility bins (Lane et al., 2008a; Murphy and Pandis, 2009) in which the saturation concentration $C^{*}$ of SVOC at a temperature of $300 \mathrm{~K}$ ranges from 1 to $10^{3} \mu \mathrm{g} \mathrm{m}^{-3}$ with a factor of ten between two classes. This scheme was initially developed and used with the gas phase SAPRC99 mechanism (Carter, 2000). In this mechanism, VOC species are combined into different lumped species (Table $\mathbf{S} 2$ in the Supplement). In our work, lumped species from the SAPRC 99 mechanism are only used for SOA formation, and do not interfere with gas phase chemistry. According to SAPRC99, anthropogenic VOC (AVOC) emissions used for the simulation of SOA were regrouped into 6 lumped species including alkanes with 5 and 6 carbon atoms and more than 7 carbon atoms; a class of terminal alkenes; a class of all internal and cyclic alkenes; a class of toluene, benzene, and ethylbenzene; and a class of xylenes, tri-methylbenzenes, ethyltoluene, and higher aromatics. Two types of biogenic VOCs, monoterpene and isoprene, are taken into account (Table S2 in the Supplement). Parameters for sesquiterpene oxidation were also developed in Lane et al. (2008a), but this class of compounds is not accounted for in this study as no emission estimates are available.

SOA yields for the different VOC groups listed in Table S3 in the Supplement and for the four volatility bins have been obtained by fitting them to a large number of chamber measurements representative for urban (high $\mathrm{NO}_{\mathrm{x}}$ ) and regional (low $\mathrm{NO}_{\mathrm{x}}$ ) pollution (Lane et al., 2008a and references herein).

In this study, we choose to apply the yield parameterizations (Murphy and Pandis, 2009; Lane et al., 2008b) for SOA simulations under low- $\mathrm{NO}_{\mathrm{x}}$ conditions $\left(\mathrm{VOC} / \mathrm{NO}_{\mathrm{x}}\right.$ $>10 \mathrm{ppbC} \mathrm{ppb}^{-1}$ ) with relatively high yields, though high$\mathrm{NO}_{\mathrm{x}}$ conditions with lower yields were probably expected for SOA formation from anthropogenic VOCs in the Paris agglomeration and in its plume. However, under conditions of long-range transport of SOA to the agglomeration, which 
were prevailing during the campaign (Freutel et al., 2013), these yields are appropriate. Besides, the larger SOA yields under low- $\mathrm{NO}_{\mathrm{x}}$ conditions are still compatible with results of some of the chamber studies for high- $\mathrm{NO}_{\mathrm{x}}$ conditions ( $\mathrm{Ng}$ et al., 2006; Hildebrandt et al., 2009). Other studies (e.g., Lane et al., 2008a) have used a higher aging rate, which did not improve model performance.

The chemical aging of gas phase anthropogenic and biogenic SVOCs is implemented in the model in a similar way as for OPOA (Shrivastava et al., 2011), because available experimental data suggest that second-generation products may contribute to SOA formation (Ng et al., 2007a). The chemical aging is applied to each anthropogenic SVOC regardless of its precursors. The reaction rate is taken as $1 \times 10^{-11} \mathrm{~cm}^{3}$ molecule ${ }^{-1} \mathrm{~s}^{-1}$ like in Murphy and Pandis (2009). Again, each oxidation reaction increases the species mass by $7.5 \%$ to account for added oxygen (Shrivastava et al., 2008; Murphy and Pandis, 2009). Laboratory ( $\mathrm{Ng}$ et al., 2007b) and modeling experiments (Valorso et al., 2011; Cappa and Wilson, 2012) suggest aging processes also for biogenic SVOC species. Thus a similar chemical aging scheme (using the same parameters as for anthropogenic VOC) was included for biogenic VOC precursors (as also done by Tsimpidi et al., 2010). Other applications of the VBS (Murphy and Pandis, 2009; Fountoukis et al., 2011) have assumed that the aging of the biogenic VOCs does not lead to a net increase of the corresponding aerosol because of a balance between the functionalization and fragmentation processes.

\subsection{Simulation configurations}

In this study, four model configurations have been set up for evaluation with MEGAPOLI campaign measurements.

1. One standard simulation denoted as CSS (classical single step) in which POA is considered as non-volatile, and the single-step scheme for SOA formation as described in Sect. 3.3.

2. The volatility of semi-volatile POA and the chemical aging of the related SVOC and IVOC are simulated in $V B S-T 1$. The single-step oxidation SOA scheme is used for anthropogenic and biogenic VOC precursors. Additional gas phase IVOC emissions of 1.5 times the POA emissions are added.

3. In contrast to VBS-T1, the 4-bin VBS approach for SOA formation is applied in the VBS-T2 simulation. The chemical aging of anthropogenic and biogenic SVOC is included.

4. As in (3), but the specific MEGAPOLI project emission inventory (MPOLI) is used in a simulation with the VBS-T2 configuration on the regional domain, while in configurations (1)-(3) EMEP/LA emissions are used. Simulation (4) is nested into a continental simulation as in (3), so only emissions over Northern France changed. This configuration is denoted as VBS-MPOLI.

\section{Model evaluation with ground-based measurements}

In this section, first a general evaluation of the model performance during the MEGAPOLI summer campaign is presented by comparing ground-based observations of meteorological parameters, concentrations of the gas phase pollutants as well as primary and secondary PM species with simulations. The main fine PM components compared here to measurements (BC, OA, sulfate, nitrate, and ammonium) are considered to appear in the accumulation mode or at smallersize bins. Therefore, the modeled bulk amounts (all size bins integrated) of these species can be compared to AMS (or BC) $\mathrm{PM}_{1}$ measurements. The comparison focuses on the evaluation of the different organic aerosol schemes presented above.

All measurements are averaged into hourly data in order to be comparable to model results. Time series are presented according to the above-defined four periods of different transport regimes (R1-4). Special features in time series (and the model ability to represent them) are highlighted. In addition, the daily variation of some species is discussed.

Statistical metrics are calculated in order to give objective scores for the model performance. They are presented as absolute and relative bias, (relative) root mean square error (RMSE) and correlation coefficient $(R)$. The detailed statistical results are presented in the Supplement.

Like the modification of OA simulations in CSS, VBS-T1 and VBS-T2 with the same emission inventory affect simulations of other species either only marginally or not at all; their concentrations are all taken from the VBS-T2 simulation and evaluated together with those from the VBS-MPOLI run.

\subsection{Evaluation of meteorological parameters}

Meteorological parameters such as $10 \mathrm{~m}$ wind and $2 \mathrm{~m}$ temperature from the MM5 simulation are compared to the measurement data obtained from the automatic meteorological station located at the suburban SIRTA observatory within the Paris agglomeration. The results are used to evaluate the simulation of meteorological parameters which are expected to represent the weather conditions in the Paris agglomeration.

In general, the variation of simulated meteorological parameters is consistent with observations (Fig. 2). Wind speed at $10 \mathrm{~m}$ height correlates well between the MM5 results and measurements at SIRTA $(R=0.73)$; a positive bias (relative bias) of $+1.07 \mathrm{~m} \mathrm{~s}^{-1}(+35 \%)$ and RMSE (relative RMSE) of $1.64 \mathrm{~m} \mathrm{~s}^{-1}(53 \%)$ is found (Table S4 in the Supplement). A small forest is located at about $100 \mathrm{~m}$ north of the measurement site, which may lead to lower local wind speed and partly explain the apparent model overestimation 
during period R1 on days with northerly wind, while the simulated wind speed at $200 \mathrm{~m}$ is consistent with the observation (results not shown). The simulated wind direction from the MM5 model is also generally consistent with measurements. Differences in wind direction and speed often occurred when wind speed was lower than $1 \mathrm{~m} \mathrm{~s}^{-1}$, such as during R2. Under such conditions, meso-scale meteorological models cannot be expected to give reliable wind speeds and directions. The simulated and measured temperatures are well correlated $(R=0.92)$; the average simulated temperature is underestimated by $0.86 \mathrm{~K}$. The daily temperature peak is sometimes underestimated by up to $5 \mathrm{~K}$, which may theoretically cause an underestimation of biogenic VOC emissions, and thus of ozone and SOA formation. However, many other uncertainties affect biogenic VOC emissions. Nevertheless, biogenic VOC levels in the Paris agglomeration are reasonably well predicted in the model as illustrated in Fig. S4 in the Supplement (see Sect. 4.2). The RMSE for simulated/observed temperature is $1.93 \mathrm{~K}$. For the three observed periods with enhanced temperatures over $300 \mathrm{~K}$ (R1, R2 and R3 as described in Sect. 2), simulations show a negative bias.

The boundary layer height was derived from aerosol lidar measurements using an algorithm detecting maximal vertical and temporal gradients in the backscatter signal (Haeffelin et al., 2012). The assumption is that the aerosol is mixing in the boundary layer, while the free troposphere above is nearly particle free. This is particularly true under daytime convective conditions where the strongest aerosol gradients are found at the top of the boundary layer. The PBL height diagnosed in the MM5 model with the MRF (mediumrange forecast) scheme (Hong and Pan, 1996) underestimates this derived boundary layer height by about $300 \mathrm{~m}$ on a monthly average basis. This mainly results from the maximum late-afternoon PBL peak height which is underestimated by $600 \mathrm{~m}(\sim 30 \%)$ on average (Fig. S2 in the Supplement). On several occasions, the PBL height underestimation was more pronounced, up to $1000 \mathrm{~m}$ for an observed PBL height of about $3000 \mathrm{~m}$. The transition of the high convective boundary layer in the evening to a stable lower boundary layer is on average simulated to occur $2-3 \mathrm{~h}$ earlier than observed. These differences lead to a low correlation coefficient of 0.37 between simulations and observations. The difficulty in simulating the evening and the nighttime PBL height was also reported in previous studies in Mexico City with MM5 (Hodzic et al., 2009) and WRF models (Fast et al., 2009), even if this effect is more pronounced in the current study. In addition, it was reported that the lidar-derived PBL height could not unambiguously distinguish the shallow inversion layer that forms in the late afternoon, when the sensible heat flux is reduced, from the top of the residual layer. This may induce a positive bias of $300-1000 \mathrm{~m}$ in the PBL height diagnosed from lidar observations, as compared to the one deduced from radiosonde profiles (Hodzic et al., 2009). Thus, during late afternoon, both the simulated and observationderived boundary layer heights are uncertain. The underes- timation of the simulated PBL height in the late afternoon might lead to an overestimation of the pollution level; however, this is difficult to quantify because of the uncertainty in the observed boundary layer height.

On the whole, simulations of meteorological parameters represent the general weather conditions for the Paris agglomeration during the summer MEGAPOLI campaign reasonably well and can serve as an input to the CHIMERE CTM.

\subsection{BC, $\mathrm{NO}_{\mathrm{x}}$ and VOC evaluation}

The concentrations of primary pollutants mainly depend on their emissions, and on meteorological conditions governing their dispersion. The model evaluation of $\mathrm{NO}_{\mathrm{x}}$ and $\mathrm{BC}$ at the three primary sites thus gives insight into the correctness of emissions and dispersion conditions over the urban area. Note that for BC additional uncertainty can arise if emission factors in the inventories have been determined by EC instruments and are compared here to $\mathrm{BC}$ measurements, given the sometimes large differences between the two methods (Oladoyin Salako et al., 2012).

$\mathrm{NO}_{\mathrm{x}}\left(\mathrm{NO}+\mathrm{NO}_{2}\right)$ is analyzed as a primary pollutant family, as freshly emitted $\mathrm{NO}$ is quickly oxidized into $\mathrm{NO}_{2}$ over a city. $\mathrm{NO}_{\mathrm{x}}$ concentrations modeled in VBS-T2 (with the EMEP emission inventory) and VBS-MPOLI (the MEGAPOLI emission inventory) at the three principal sites are reasonably well correlated with the measurements with correlation coefficients around 0.55 at GOLF and LHVP and 0.65 at SIRTA (Fig. 3). These correlation coefficients are consistent with previous modeling studies in Europe (e.g., Beekmann et al., 2007). Simulated $\mathrm{NO}_{\mathrm{x}}$ levels are overestimated in VBS-T2 with biases (and relative biases) of +6.1 $(+45 \%),+2.7(+15 \%)$ and $+1.7 \mathrm{ppb}(+21 \%)$ at GOLF, LHVP and SIRTA, respectively (Table S5 in the Supplement). Use of the MEGAPOLI emission inventory (MPOLI) results in an even larger overestimation with (relative) biases of $+10.0(+95 \%),+7.2(+42 \%)$, and $+1.6 \mathrm{ppb}(+22 \%)$, respectively (Table S6 in the Supplement). The relative RMSEs from VBS-T2 (and VBS-MPOLI) are $86 \%(148 \%)$, $80 \%(104 \%)$ and $69 \%(84 \%)$, respectively, for these three sites. As differences between total French emissions in both emission inventories are small (because the same national emission totals are used as input), these differences in the comparison to urban observations are probably related to the spatial downscaling procedure (see Sect. 3.2). The bias at SIRTA is relatively smaller than at GOLF and LHVP, because SIRTA is less influenced by Paris emissions during this summer campaign due to prevailing westerly to southwesterly winds. The average daily variation over the month of both of the simulations and observations shows peaks at these sites at about 07:00-08:00 local time (LT) (Fig. 3). Morning peaks are slightly overestimated by $20-30 \%$ in the model at GOLF and SIRTA in VBS-T2, while they are overestimated up to about $75 \%$ at GOLF in VBS-MPOLI. No clear 

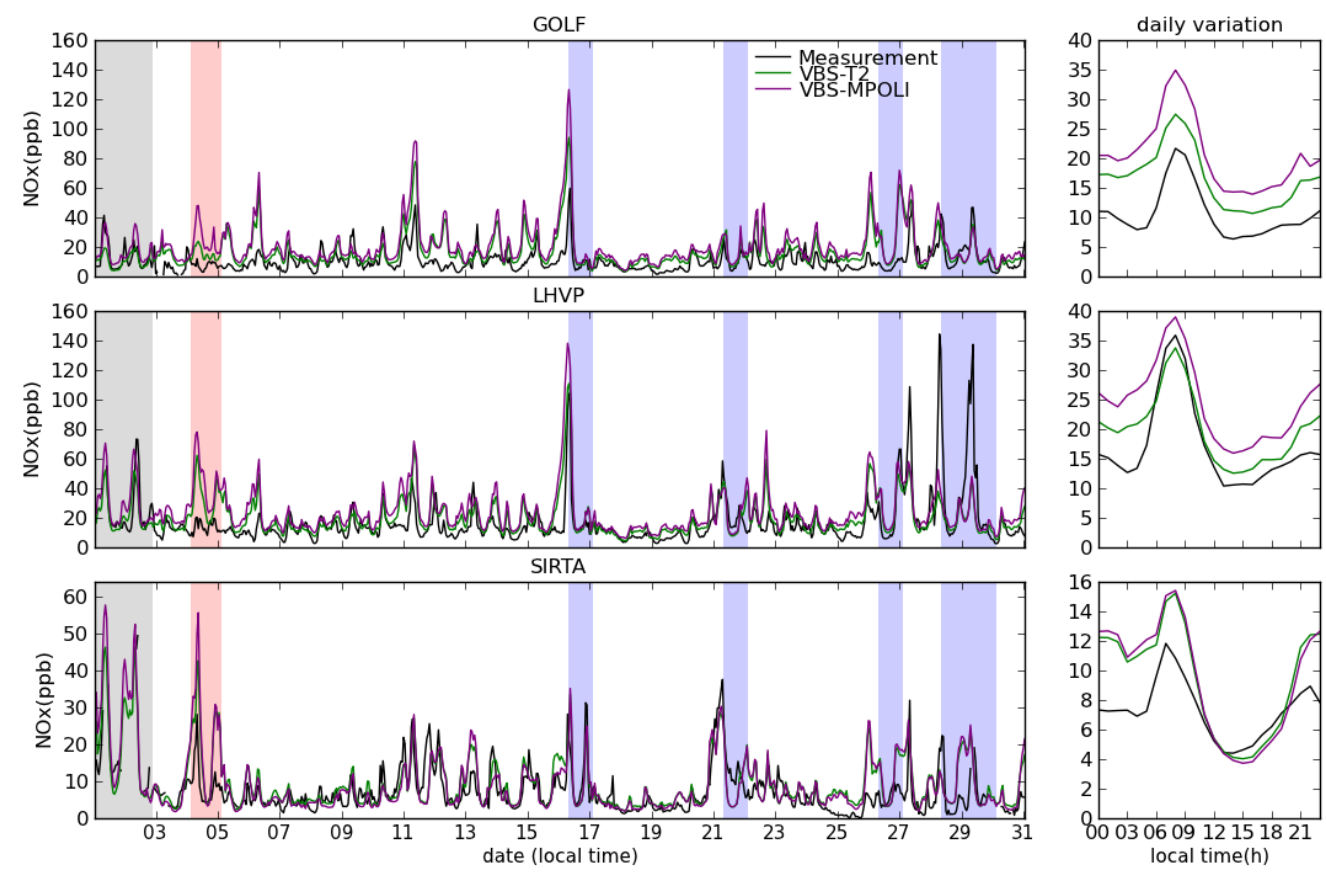

Fig. 3. Comparison of simulated and observed $\mathrm{NO}_{\mathrm{x}}$ at GOLF, LHVP and SIRTA. On the left side, time series; on the right side, hourly averages for July 2009.
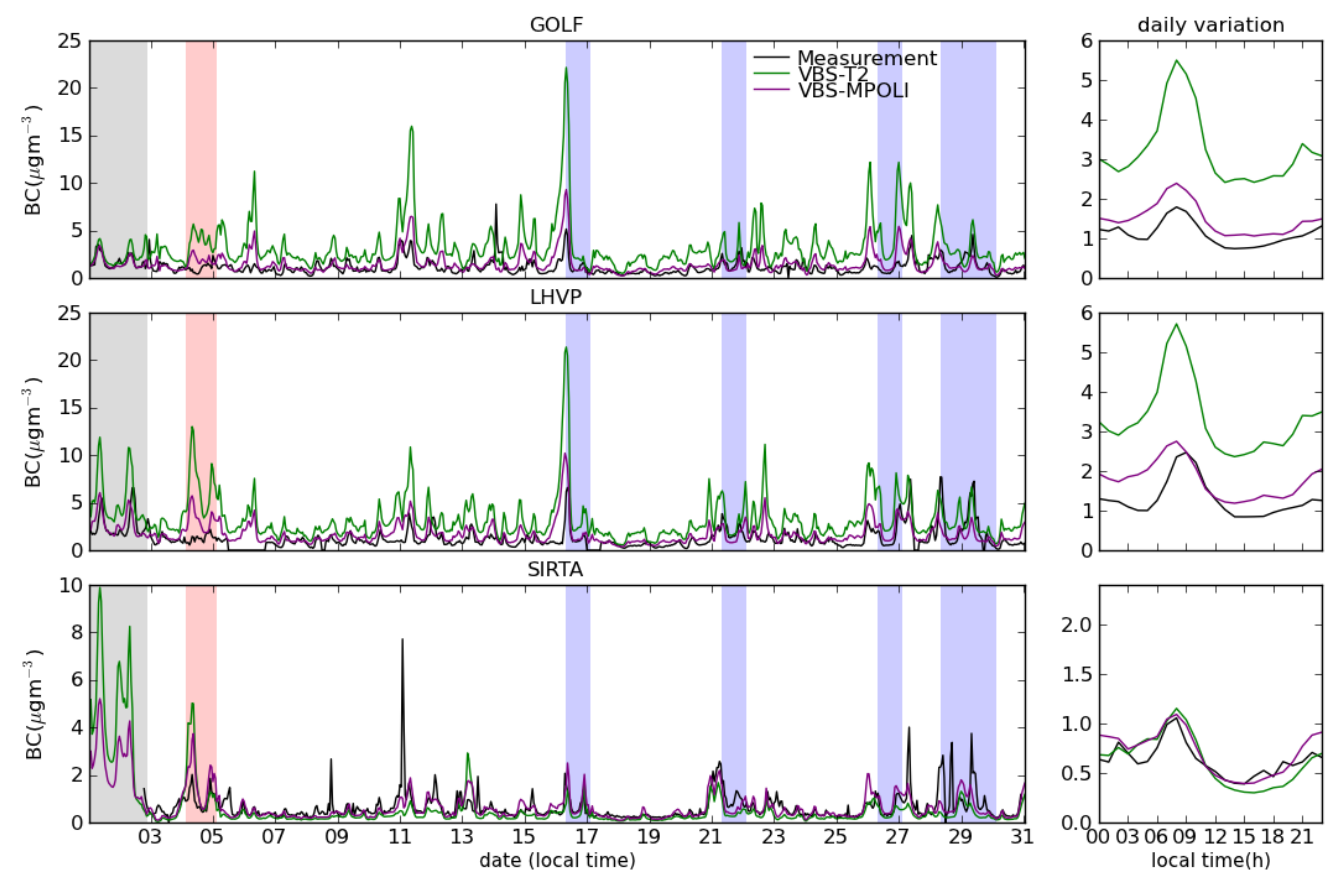

Fig. 4. As in Fig. 3, but for BC.

evening peaks have been modeled or measured at these sites (rather a continuous increase during evening and night), indicating that vertical mixing is still active in the late afternoon. A particular case occurred during 28 and 29 July at LHVP when $\mathrm{NO}_{\mathrm{x}}$ concentrations in both VBS-T2 and VBS-MPOLI are largely, by about 60-100 ppb, underestimated, probably due to an overestimation of wind speed (see Fig. 2). During period $\mathrm{R} 2, \mathrm{NO}_{\mathrm{x}}$ morning peaks in both VBS-T2 and VBSMPOLI are clearly overestimated with respect to observations at GOLF and LHVP, and to a lesser extent at SIRTA. 

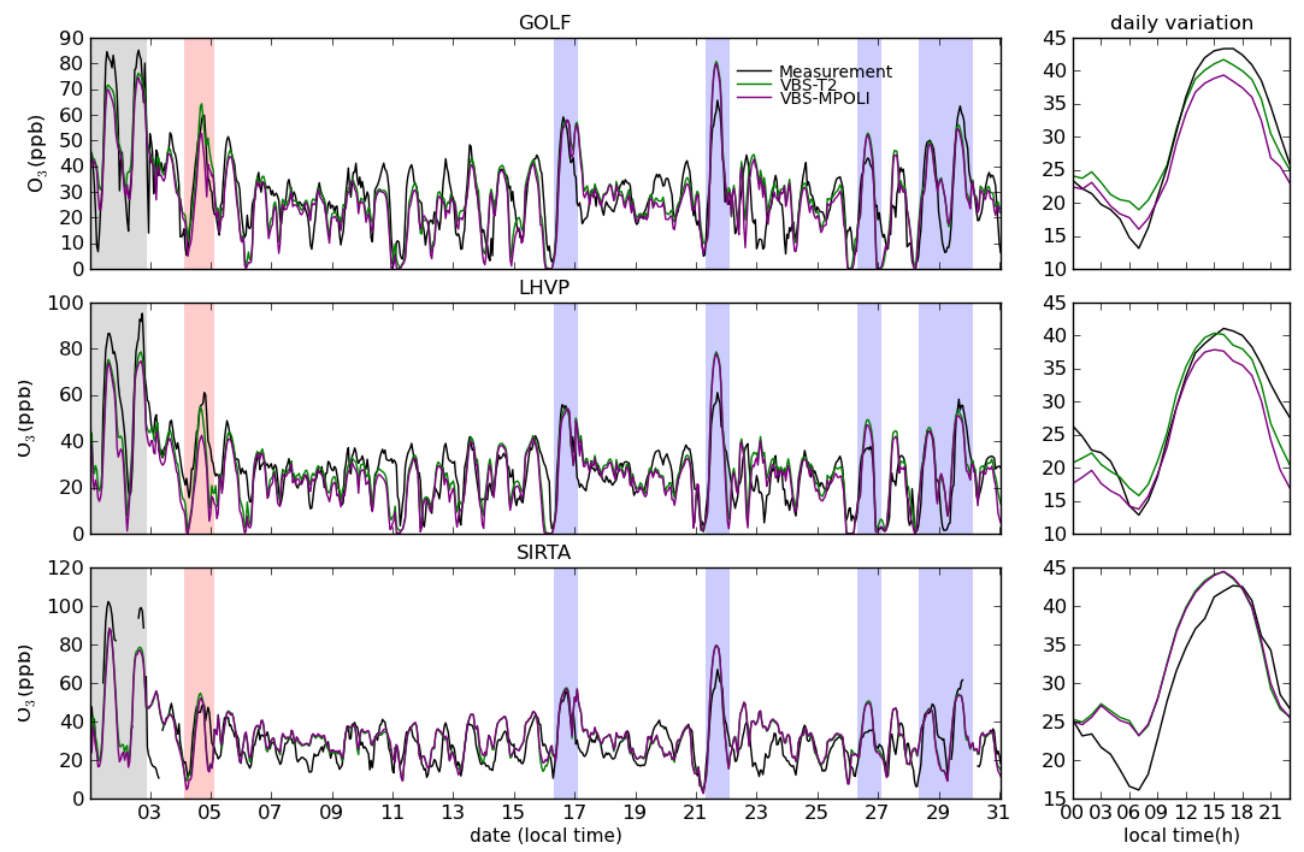

Fig. 5. As for Fig. 4, but for ozone.

This is probably due to relatively weak and variable winds during this period, which are not correctly reproduced in the simulation.

In conclusion, both VBS-T2 and VBS-MPOLI simulations overestimate the observed $\mathrm{NO}_{\mathrm{x}}$ levels, which could indicate either underestimated dispersion related to the underestimation of the boundary layer height on certain days, or an overestimation of $\mathrm{NO}_{\mathrm{x}}$ emissions in the Greater Paris region, more pronounced for the MEGAPOLI inventory than for the EMEP one. Close to source regions, sink processes (mainly reaction of $\mathrm{NO}_{2}$ with $\mathrm{OH}$ ) are probably too slow to affect $\mathrm{NO}_{\mathrm{x}}$ levels.

The correlation coefficients for simulated BC in VBS-T2 and VBS-MPOLI and for measured BC are in general around 0.5 at the three principal sites (Fig. 4). This result is coherent with that obtained for $\mathrm{NO}_{\mathrm{x}}$. The correlation coefficient is only 0.36 at SIRTA in the VBS-T2 simulation, probably due to the difficulty of correctly reproducing the very low level of $\mathrm{BC}$ at this site, which was mostly located upwind of Paris emissions during this campaign. The biases (and relative biases) for comparison between simulated BC in VBS-T2 and measured $\mathrm{BC}$ are $+2.07(+180 \%),+2.08(+167 \%)$ and $-0.24 \mu \mathrm{g} \mathrm{m}^{-3}(-38 \%)$ at GOLF, LHVP and SIRTA, respectively (Table S5 in the Supplement). They are much larger than those for $\mathrm{NO}_{\mathrm{x}}$, though $\mathrm{NO}_{\mathrm{x}}$ and $\mathrm{BC}$ are mostly trafficrelated in the city. The biases (relative biases) are +0.33 $(+29 \%),+0.52(+41 \%)$ and $-0.05 \mu \mathrm{g} \mathrm{m}^{-3}(-7.3 \%)$ for VBS-MPOLI (Table S6 in the Supplement).

The overestimation in VBS-T2 is most likely a result of an overestimation of $\mathrm{BC}$ emissions from the LA emission inventory because the underestimation of the PBL height is too small to explain such large differences present during the whole day. Such an overestimation is also suggested by the slope of $\mathrm{BC}$ with respect to $\mathrm{NO}_{\mathrm{x}}$ at LHVP, which is clearly higher in VBS-T2 $\left(0.18 \mu \mathrm{g} \mathrm{m}^{-3} \mathrm{ppb}^{-1}\right)$ than in the measurements $\left(0.06 \mu \mathrm{g} \mathrm{m}^{-3} \mathrm{ppb}^{-1}\right)$, while it is $0.07 \mu \mathrm{g} \mathrm{m}^{-3} \mathrm{ppb}^{-1}$ from VBS-MPOLI with the MEGAPOLI inventory (Fig. S3 in the Supplement). Thus the latter inventory, into which refined urban $\mathrm{BC}$ emission data for the Paris agglomeration have been integrated (see above), appears to be more accurate for BC. Conversely, BC is slightly underestimated in the model in both VBS-T2 and VBS-MPOLI simulations at SIRTA, which was often located upwind of Paris during periods $\mathrm{R} 3$ and $\mathrm{R} 4$, inducing a relatively low level of measured average $\mathrm{BC}$ concentration of about $0.64 \mu \mathrm{g} \mathrm{m}^{-3}$. The average daily variation of both measured and modeled $\mathrm{NO}_{\mathrm{x}}$ and $\mathrm{BC}$ are correlated at these three sites with peaks around 08:00 LT.

Predicted major VOC precursors for SOA formation are evaluated with the GC-FID and PTRMS measurements (Fig. S4 in the Supplement). The mean concentrations of isoprene are $0.24,0.22$ and $0.43 \mathrm{ppb}$ in the model and from GC-FID and PTRMS $(\mathrm{m} / \mathrm{z}, 69)$ measurements, respectively. The predicted bulk mono-terpenes concentration is on a similar level $(\sim 0.06 \mathrm{ppb})$ as the observed one from PTRMS $(\mathrm{m} / \mathrm{z}$ 137). Considering measurement uncertainties, these results imply a reasonably well simulated average level of biogenic VOC in the model. The variability is also well represented; larger observed and predicted values occur in periods $\mathrm{R} 1$ and R3 when winds are low and temperature enhanced.

Lumped anthropogenic aromatics are compared to the sum of the measurements of benzene, toluene, xylenes, ethylbezene, n-propylbenzene, 1,3,5-TMB, o-ethyltoluene and 


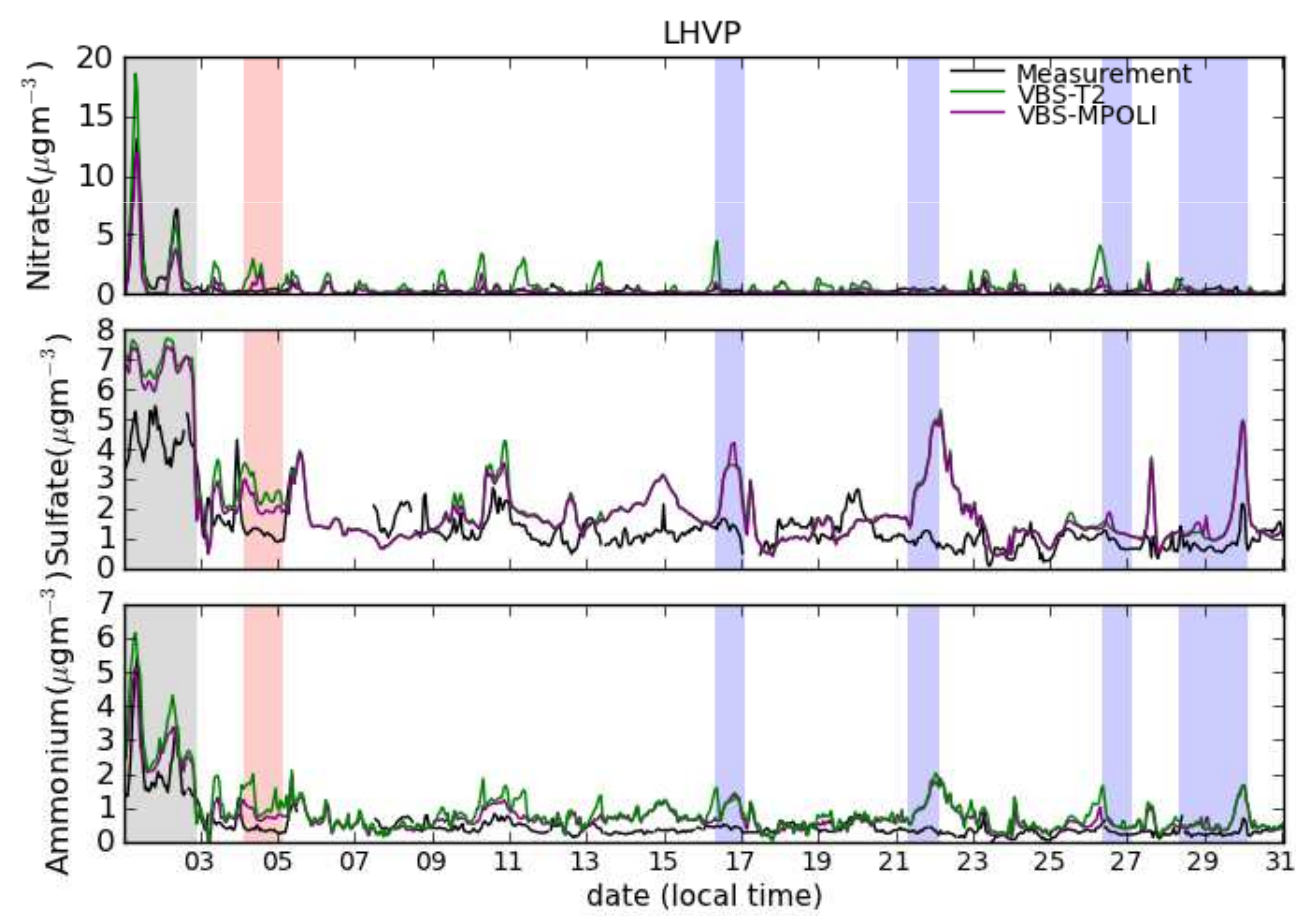

Fig. 6. Comparison of simulated and observed inorganic aerosol species at LHVP.

1,2,4-TMB from GC-FID, which are the major aromatics in the urban region, and the sum of $\mathrm{m} / \mathrm{z} 79,93,107$ and 121 (which correspond to the sum of benzene, toluene, aromatic C8 and aromatic C9) from PTRMS (Fig. S4 in the Supplement). The model overestimates the sum of the aromatic species by about $48 \%$ and $82 \%$ with respect to the measurements from PTRMS and GC-FID, respectively. This is partly due to an underestimation of dispersion as for $\mathrm{NO}_{\mathrm{x}}$ and $\mathrm{BC}$. However, measurements probably do not represent all emitted aromatic species. Thus, the aromatic species are probably reasonably well predicted.

Higher alkanes grouped in model species are not evaluated because of a lack of measurements for a large part of the lumped species in the model.

\subsection{Ozone evaluation}

Similar to other secondary pollutants, lower-tropospheric ozone is generally photochemically produced in summer. Thus, the evaluation of ozone simulations against the measurements may allow assessing the simulated photochemical activity over the agglomeration and in advected air masses which also affects the formation of secondary organic aerosol. In addition, ozone is an important oxidant to react with biogenic VOC precursors to form secondary organic aerosol. Therefore, it is important to evaluate the performance of ozone simulations in the model.

Modeled ozone concentrations both from VBS-T2 and VBS-MPOLI at the three primary sites correlate well with the measured concentrations $(R \sim 0.75)$ with small relative biases below $13 \%$ (Fig. 5, Tables S5 and S6 in the Supplement). Elevated ozone levels are linked both in the model and in observations to relatively high temperatures, frequently low winds and sunny conditions during periods $\mathrm{R} 1, \mathrm{R} 2$ and R3. These conditions are favorable for photochemical ozone build-up. Modeled concentrations at GOLF and LHVP are lower in VBS-MPOLI due to higher $\mathrm{NO}_{\mathrm{x}}$ levels in VBSMPOLI than in VBS-T2 and thus enhanced ozone titration with NO. In the diurnal cycle, predicted and observed maximum values occur at about 16:00-17:00 LT as a result of lower $\mathrm{NO}_{\mathrm{x}}$ values and more intense photochemical activity around noon.

\subsection{Evaluation of inorganic aerosol species}

Although the focus here is on organic aerosol, for completeness also inorganic aerosol is evaluated because of its important contribution to fine PM. The modeled secondary inorganic salt (sulfate, nitrate and ammonium) concentrations from both VBS-T2 and VBS-MPOLI simulations are generally overestimated with respect to the AMS measurements during the campaign (Fig. 6 and Figs. S5 and S6 in the Supplement). The modeled monthly average concentrations of the inorganic aerosol (here sum of sulfate, nitrate and ammonium) in VBS-T2 and VBS-MPOLI are overestimated by about $1.5-2 \mu \mathrm{g} \mathrm{m}^{-3}$ and $1-1.5 \mu \mathrm{g} \mathrm{m}^{-3}$, respectively (Tables S5 and S6 in the Supplement). The correlation coefficients of these inorganic species are almost all above about 

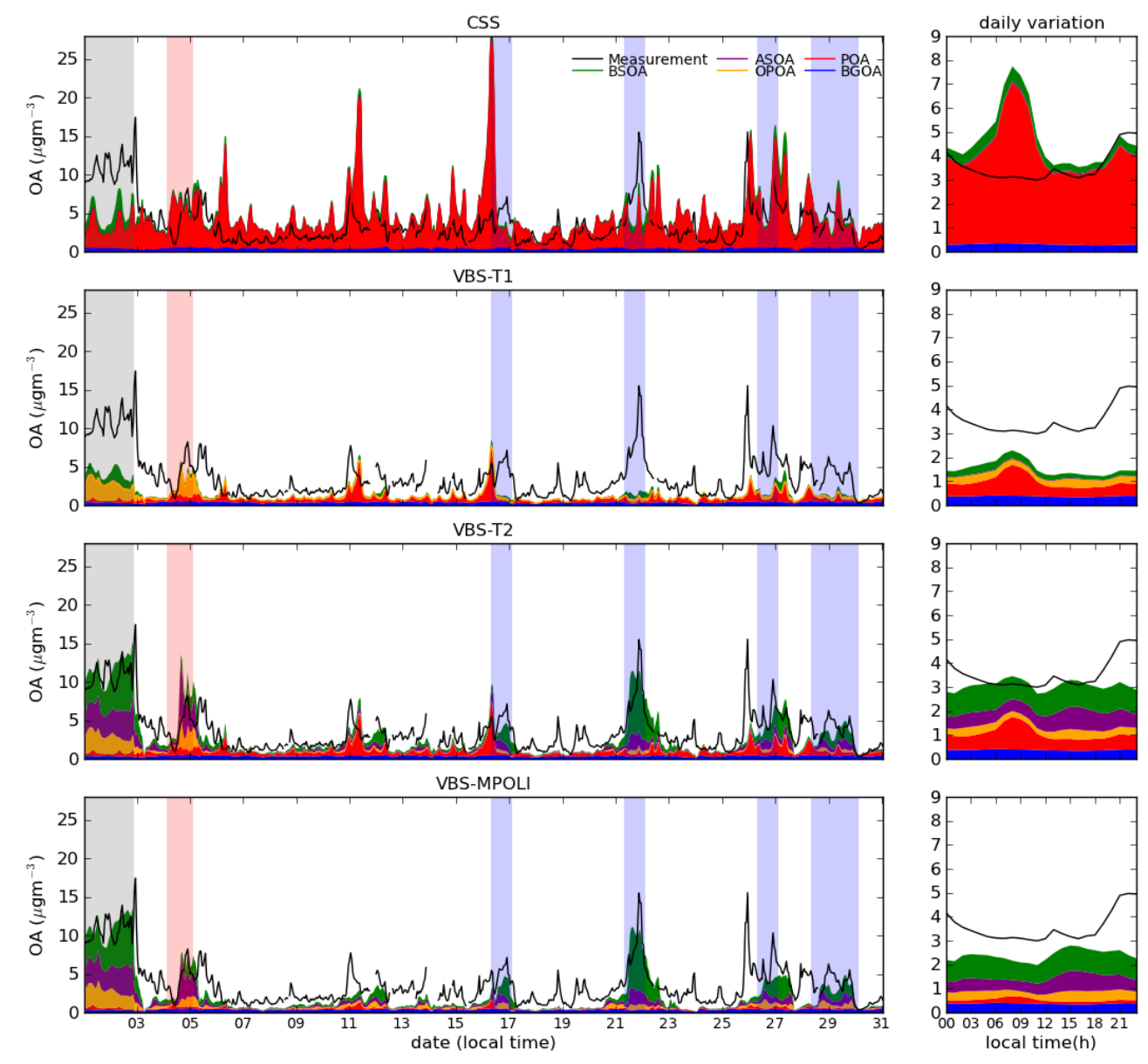

Fig. 7. Comparison of simulated and observed organic aerosol at GOLF. On the left side, time series; on the right side, daily averages for July 2009.

0.7 at GOLF and LHVP. Those of sulfate and ammonium are slightly lower at SIRTA.

The measured nitrate concentrations were very low (close to zero) except for the first two days of continental influence. This can lead to very large relative biases (Table S5 in the Supplement); therefore here only the absolute differences are presented. There are often overestimations of nitrate peaks in the morning due to local formation in VBS-T2. Conversely, the peaks in VBS-MPOLI are largely reduced to a level similar to observed ones; the average bias is reduced to around $+0.1 \mu \mathrm{g} \mathrm{m}^{-3}$. $\mathrm{NO}_{\mathrm{x}}$ levels are lower in VBST2 than in VBS-MPOLI, thus the overestimation of nitrate concentrations in VBS-T2 is probably related to higher $\mathrm{NH}_{3}$ emissions in VBS-T2 in the urban region, due to errors in the spatial redistribution of agricultural $\mathrm{NH}_{3}$ emissions from the EMEP grid (50 km resolution) to the CHIMERE grid $(3 \mathrm{~km}$ resolution). In the MEGAPOLI inventory, a more realistic spatial distribution of $\mathrm{NH}_{3}$ emissions is achieved through geographically locating agricultural surfaces. Unfortunately, no specific $\mathrm{NH}_{3}$ observations were available to evaluate the urban $\mathrm{NH}_{3}$ concentrations.
Modeled sulfate concentrations in both VBS-T2 and VBSMPOLI have similar time series at all three sites, since sulfate is mainly formed on a regional scale where the emissions in VBS-T2 and VBS-MPOLI are similar or equal. Sulfate levels are higher during R1 when continental air masses are advected to Paris. Background concentrations and several peaks are all overestimated in simulations. This could be due to overestimated uncertainties related to the formation process in the simulations (not shown here) with respect to the measurement at SIRTA (Michoud et al., 2012), which could increase sulfate formation. However, we cannot conclude whether this is representative of the larger domain.

\subsection{OA evaluation}

Modeled OA concentrations, represented by the sum of background OA (long-range transported OA from the boundary limit of the simulation), POA, OPOA, ASOA and BSOA from the four model configurations described above, are compared to the AMS measurements at the three sites (Figs. 7, 8 and 9). At GOLF and LHVP and for the monthly 

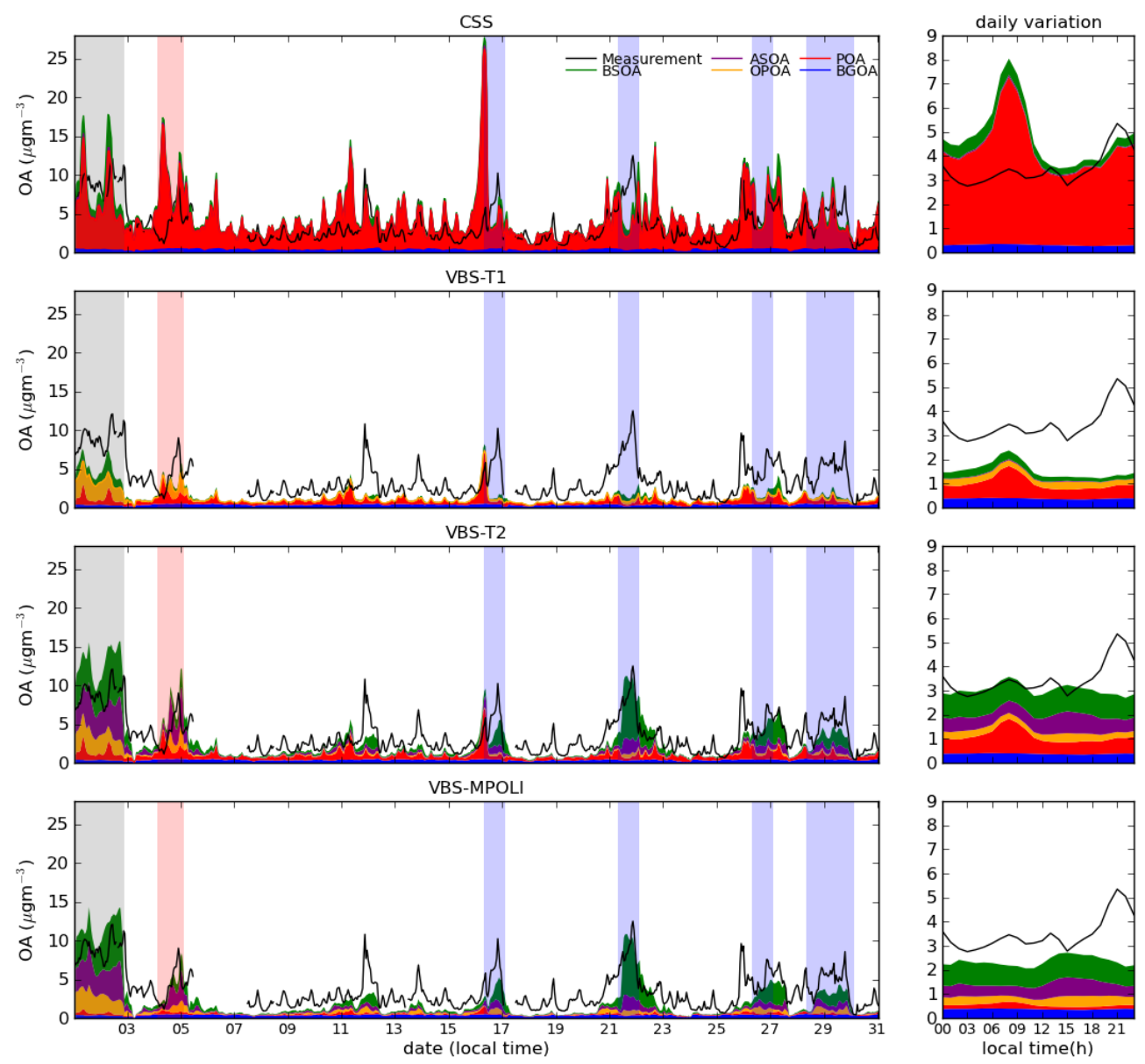

Fig. 8. As in Fig. 7, but for LHVP

average, OA simulated in CSS (see Sect. 3.5) overestimated the morning peaks by about a factor of two, while for the rest of the day the levels are consistent with the observations. POA is predicted to contribute about $90 \%$ of the simulated OA. Conversely, OA is underestimated at SIRTA, especially the peaks during R3 with southerly wind. This is because SIRTA is often situated upwind of Paris emissions during R3 and R4, in contrast to GOLF and LHVP, so it is less influenced by primary emissions than these sites. The biases (relative biases) are $+1.17(+33 \%),+1.53(+46 \%)$, and $-1.11 \mu \mathrm{g} \mathrm{m}^{-3}(-49 \%)$ at GOLF, LHVP and SIRTA, respectively (Table S5 in the Supplement). The modeled and measured OA concentrations are not well correlated, with $R$ values only reaching $0.22,0.43$ and 0.66 , respectively, at the three sites.

The modeled OA in the VBS-T1 simulation is much lower than in the CSS simulation, both for the morning peaks and the rest of the day. This is due to the fact that a substantial fraction of emitted POA is evaporated in this scheme, which diminishes simulated POA levels by a factor of about 6.5 at GOLF, LHVP and SIRTA. The secondary fraction is increased by introducing OPOA especially during R1 when continental pollution is advected to Paris (Figs. 11, 12 and 13), but this does not compensate for the lower POA levels. As a result, the VBS-T1 simulation underestimates OA by more than $70 \%$ at the three sites (Table S5 in the Supplement). However, this simulation is better correlated with the measurements than the CSS one. The correlation coefficients are $0.58,0.59$ and 0.78 at GOLF, LHVP, and SIRTA, respectively (Table S5 in the Supplement).

The underestimation of modeled OA in the VBS-T2 simulation is smaller than for the VBS-T1 configuration. Average biases (relative biases) are $-0.47(-13 \%),-0.27(-8.2 \%)$ and $-0.42 \mu \mathrm{g} \mathrm{m}^{-3}(-18 \%)$ at GOLF, LHVP and SIRTA, respectively (Table S5 in the Supplement). This simulation captures almost all peaks during the summer campaign, especially several missing peaks in the CSS and VBS-T1 simulations during periods R1 and R3. Consequently, the correlation coefficients are improved to $0.79,0.76$ and 0.84 , respectively.

During R1, observations and simulations show similar OA levels at all three sites, which again indicates long-range transport of continental pollution as a major OA source. The VBS-T2 configuration predicts that the secondary fraction 

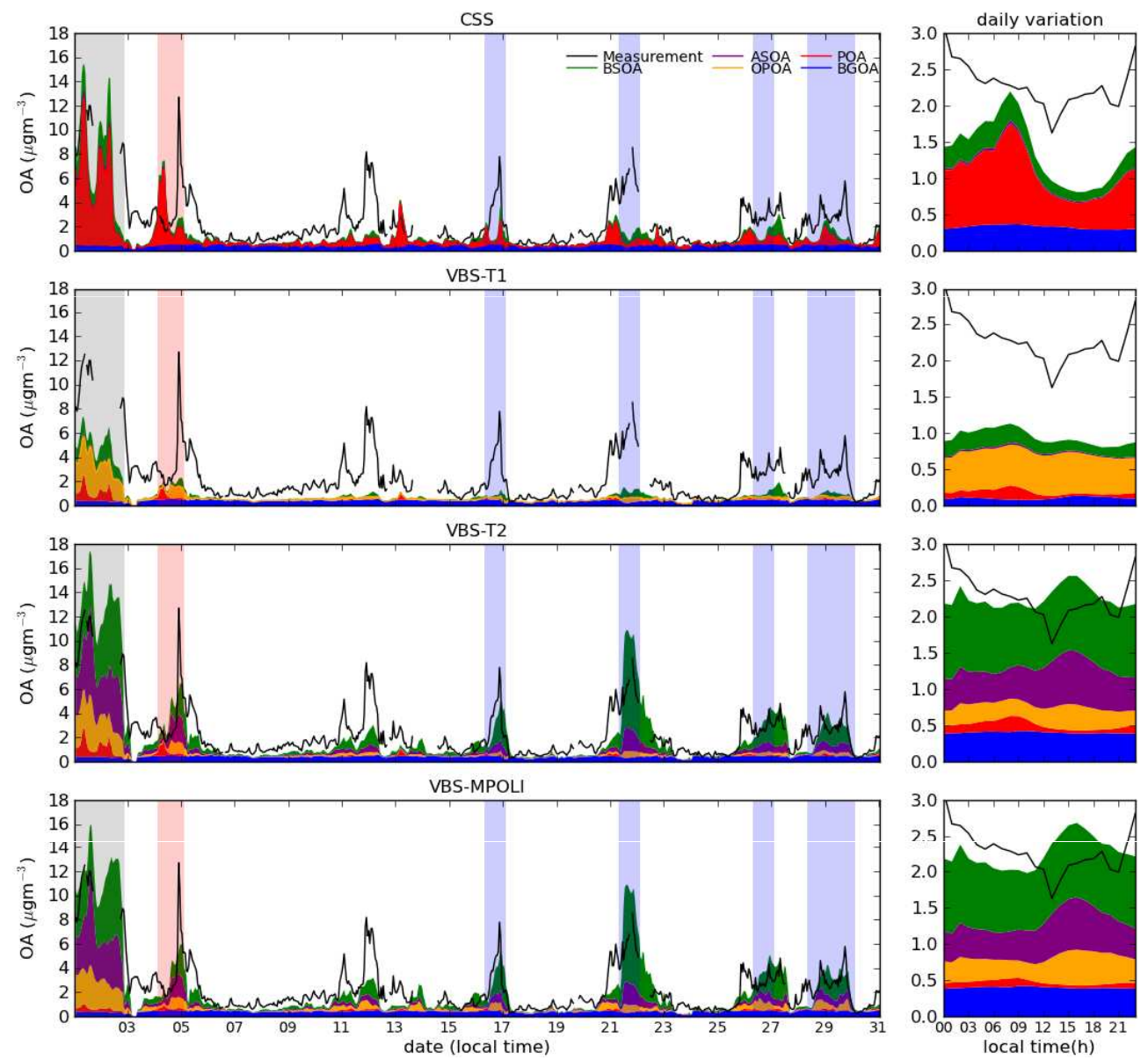

Fig. 9. As in Fig.7, but for SIRTA.

contribution of OA exceeds $90 \%$ (Figs. 11, 12 and 13). About half of this can be attributed to biogenic species. During this period starting on 30 June (R1), polluted air masses from Benelux are transported to Paris, as indicated by retroplume calculations (see for example Freutel et al., 2013). The OA of anthropogenic origin (ASOA and OPOA) is also important (Fig. 10). In addition, the time evolution of the simulated OA fields seems to indicate biogenic SOA formation from BVOCs emitted in the forest zone in the east of France and in the southwest of Germany, and its transport to Paris (Fig. 10). Paris is influenced by this polluted air mass during two days until 2 July.

During R3, the peaks in the Greater Paris region are also reproduced; in the simulations they are related to advection of biogenic SOA ( $>60 \%$ of OA in the VBS-T2 simulations) (Figs. 11, 12 and 13). This is illustrated for the SOA peak observed on 21 July. Biogenic SOA is produced from BVOC emissions in the north of Spain on 20 July and is transported towards northeast (Fig. 11). During its transport, the air mass mixes with additional BVOC emissions over SW France. During further transport to Paris, chemical aging of SVOC emissions takes place, transforming additional SVOC to SOA and reducing its volatility. Within the Ile-de-France region, additional VOC and OA emissions further increase the OA burden.

The modeled and measured average OA diurnal variations at SIRTA are very well correlated. The modeled morning peaks at GOLF and LHVP are close to the measurements, but the evening peaks are still missing, probably due to the recently found important emission sources from cooking activities (Mohr et al., 2012, and references therein; Freutel et al., 2013) which are not included in our emission inventory.

When using the MEGAPOLI emission inventory in the VBS-MPOLI simulation, the biases are $-1.15(-32 \%)$, $-0.95(-29 \%)$ and $+0.14 \mu \mathrm{g} \mathrm{m}^{-3}(+7.9 \%)$ at GOLF, LHVP and SIRTA, respectively (Table S6 in the Supplement). The correlations are similar to those for VBS-T2, but the origin of $\mathrm{OA}$ is different. The contribution of POA is low, due to lower emissions in the inventory (Figs. 11, 12 and 13). OPOA is increased with respect to VBS-T2, especially during R4. This is because the POA emissions in the Greater Paris region are reduced in the MEGAPOLI inventory with respect to the LA inventory by about a factor of 3, but they are increased on average by a factor of 3 in the surrounding 

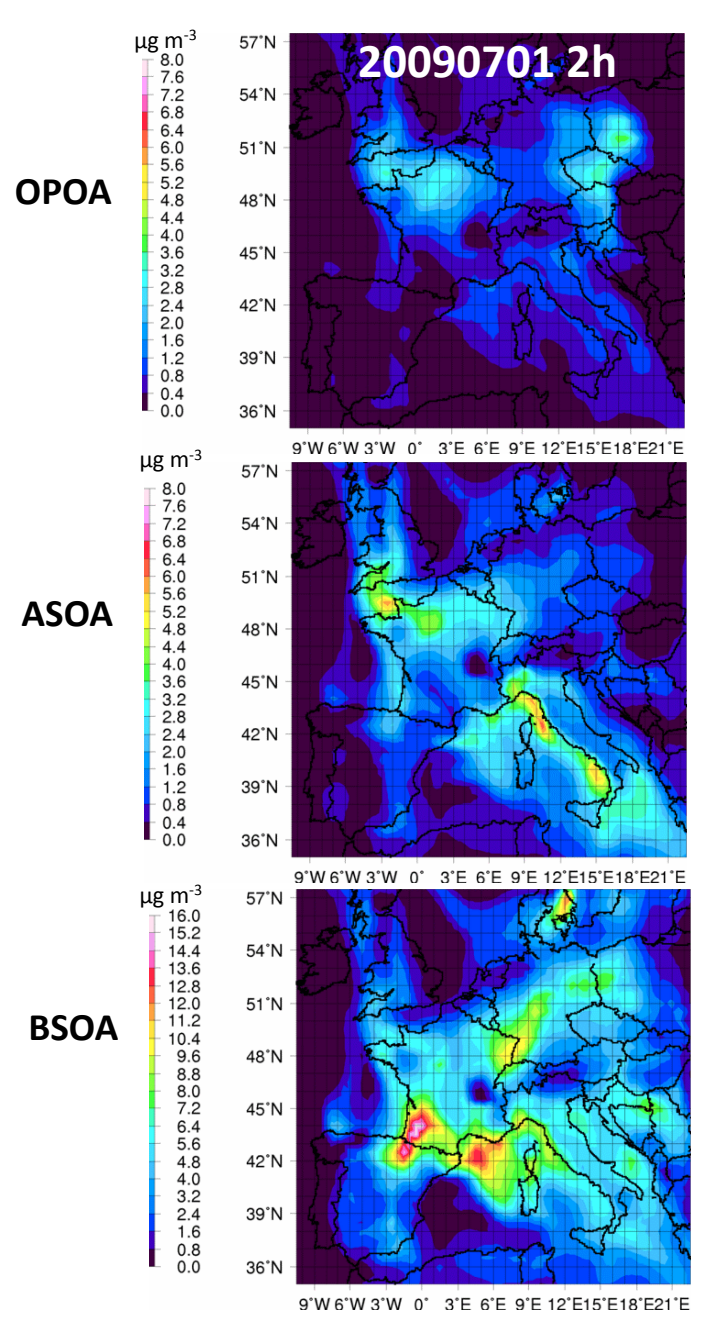
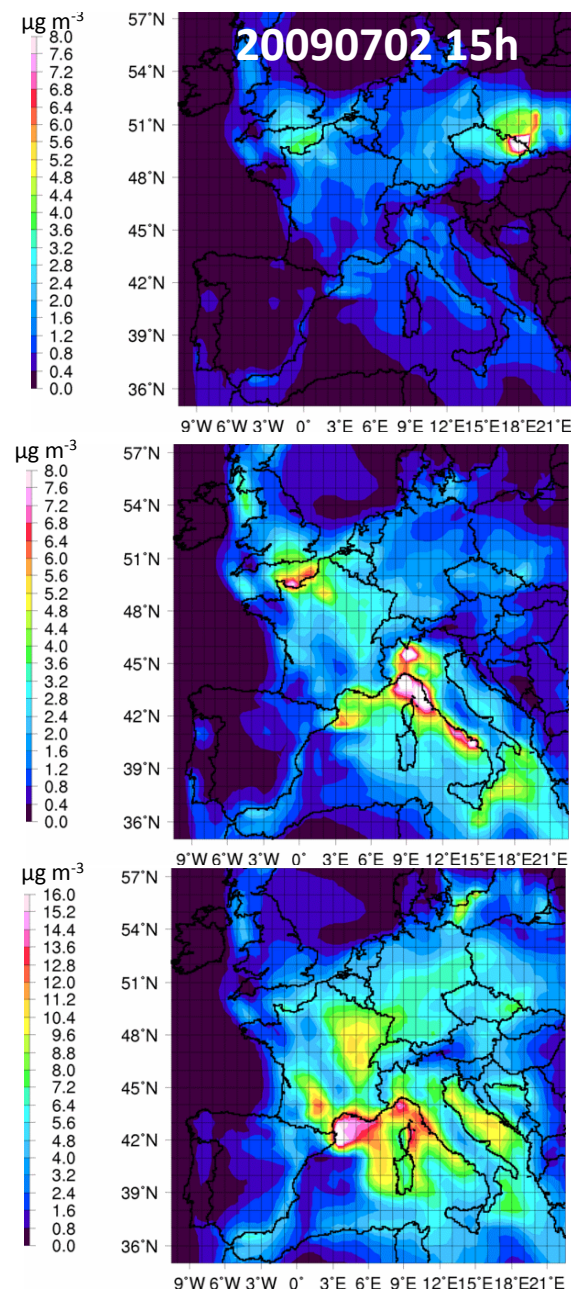

Fig. 10. Spatial OPOA, ASOA and BSOA distributions at surface level at 02:00 LT on 1 July (left) and 15:00 LT on 2 July (right).

areas in the southeast, allowing for POA evaporation and gas phase oxidation and condensation of lower volatile species to form OPOA.

\subsection{Evaluation of POA and SOA with PMF analysis atLHVP}

In this section, modeled POA and SOA from all four simulations are compared to a 3 -factor PMF analysis (Freutel et al., 2013) on OA measured by AMS at LHVP (Table 3). The three factors are traffic-related HOA, aged OA which is thought to be secondary origin (OOA), and OA related to cooking activities (see Sect. 2.1). This analysis is restricted to LHVP because at GOLF and SIRTA only a 2-factor PMF analysis is available in this PMF solution, in which possible OA from cooking activities is included in the HOA and OOA factors. Here, we focus on POA and SOA prediction at one urban background (LHVP) site, for which the 3-factor PMF solution was available. The 2-factor PMF available at all 3 sites leads to larger HOA concentrations than the 3-factor one due to the attribution of a significant part of the cooking OA to the HOA factor, but this HOA is then not consistent with the modeled one not taking into account cooking-related emissions. In the simulations, background OA (BGOA) is considered as highly aged non-volatile OA, thus contributing to the predicted SOA. OPOA is considered as OOA, as done in previous papers comparing simulations with the VBS approach to AMS observations (Robinson et al., 2007; Shrivastava et al., 2008; Murphy and Pandis, 2009; Hodzic et al., 2010, etc.). However, note that Aumont et al. (2012) and Cappa and Wilson (2012) argue that OPOA may not be oxidized enough to appear in the OOA fraction.

The modeled POA is correlated with HOA derived from the 3-factor PMF analysis with correlation coefficients of around 0.5 from all the simulations (Table S7 in the Supplement; Fig. 12). This correlation coefficient is comparable to that of other primary pollutants $\left(\mathrm{NO}_{\mathrm{x}}, \mathrm{BC}\right)$. The simulated POA slightly overestimates HOA by $+0.01(+2 \%)$ and $+0.1 \mu \mathrm{g} \mathrm{m}^{-3}(+17 \%)$ from VBS-T1 and VBS-T2 simulations, but overestimates it by $+3.42 \mu \mathrm{g} \mathrm{m}^{-3}(+55 \%)$ in the 


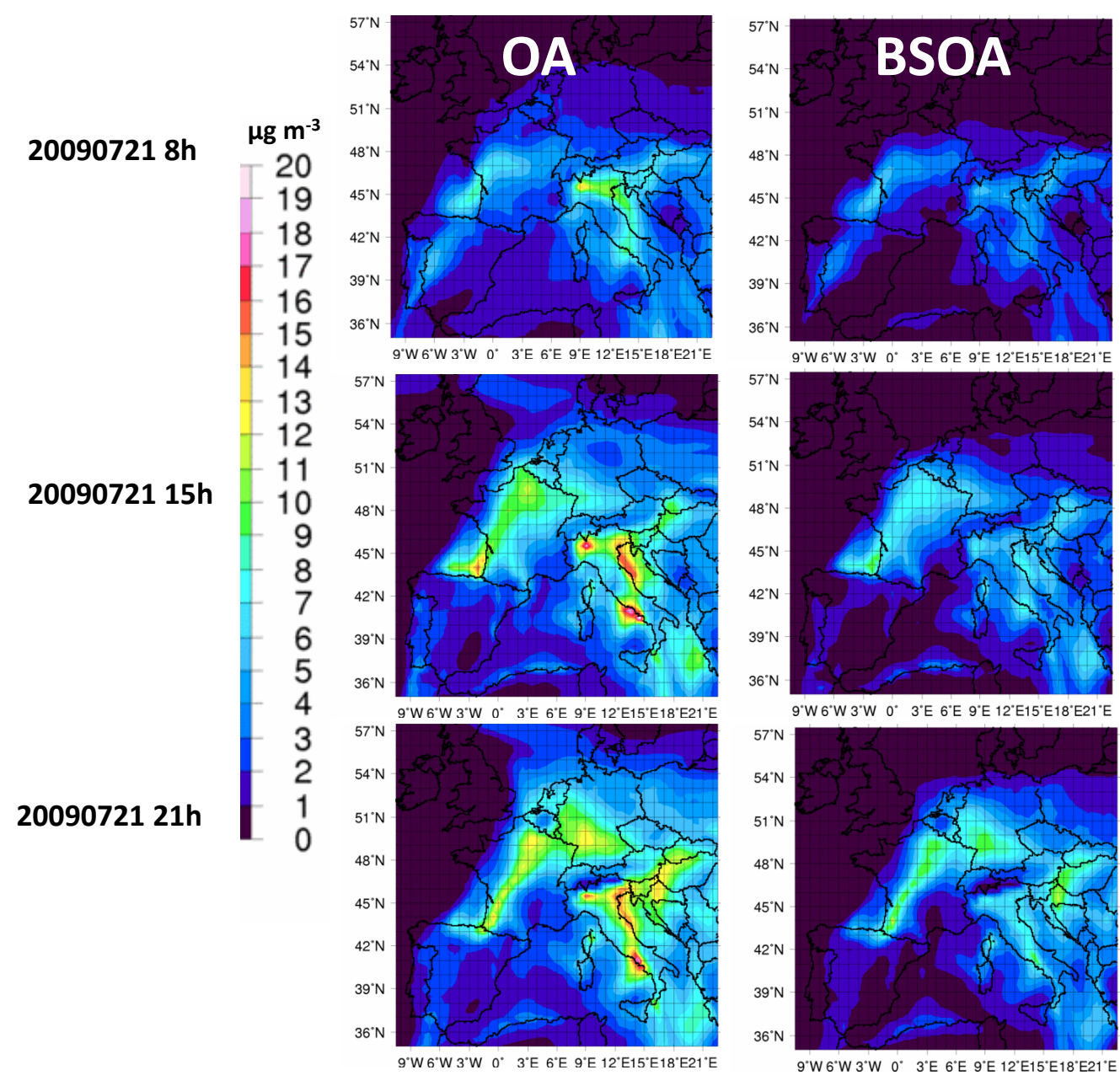

Fig. 11. Spatial OPOA, ASOA and BSOA distributions at surface level on 21 July; OA (left), BSOA (right).
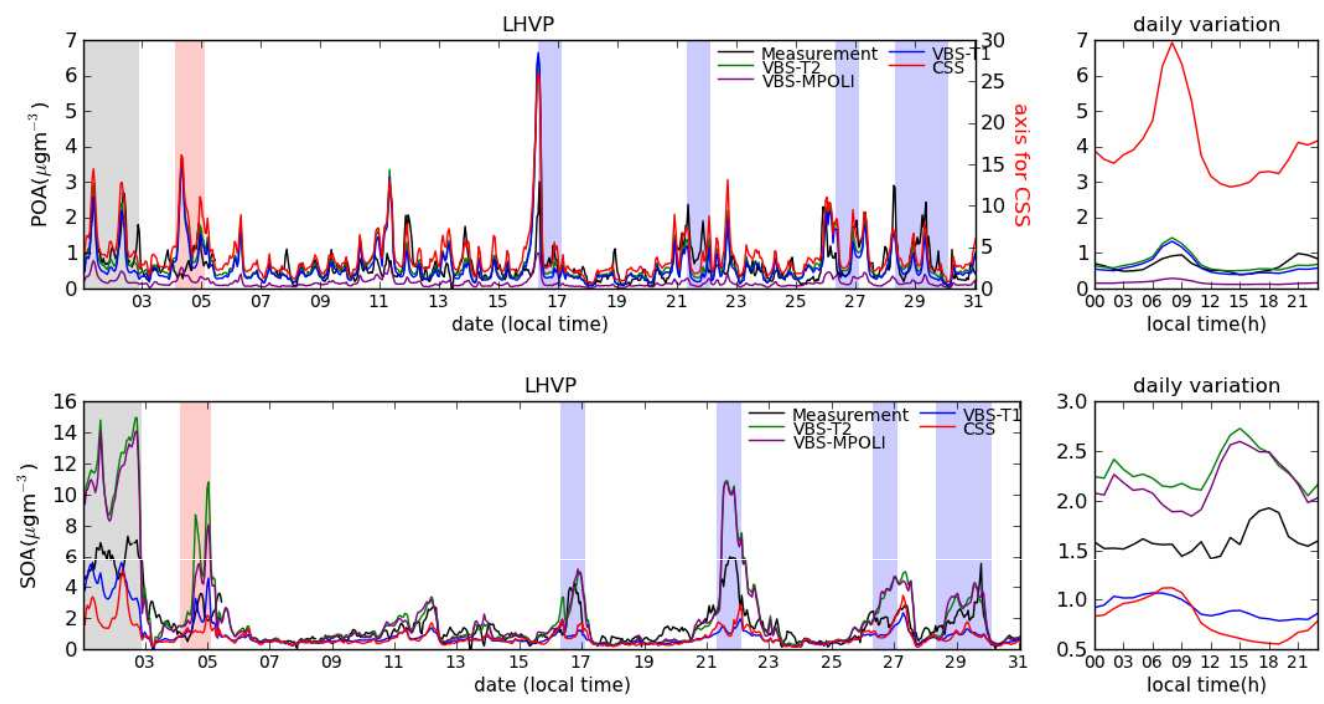

Fig. 12. Comparison of simulated and observed primary and secondary organic aerosol. 


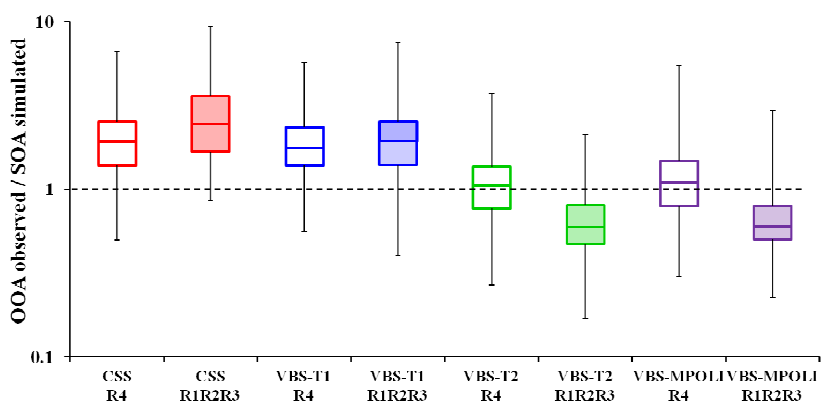

Fig. 13. OOA observed/SOA simulated ratio for clean (R4) and polluted (R1, R2, R3) periods at LHVP; boxplot for 25, 50 and 75 percentiles, and extreme values.

Table 3. Corresponding OA components in simulations and measurements.

\begin{tabular}{lll}
\hline \multicolumn{2}{c}{ Model } & $\begin{array}{l}\text { Measurement } \\
\text { AMS }\end{array}$ \\
\cline { 1 - 2 } VBS approach & Single-step scheme & AOA \\
POA & POA & HOA \\
OPOA & Not included & OOA \\
ASOA & ASOA & \\
BSOA & BSOA & \\
BGOA & BGOA & \\
Not included & Not included & COA \\
\hline
\end{tabular}

CSS simulation. The morning peak is overestimated by about $0.4 \mu \mathrm{g} \mathrm{m}^{-3}$ in the VBS-T1 and VBS-T2 simulations, possibly also due to a problem in dispersion, which is probable also for $\mathrm{NO}_{\mathrm{x}}$ and $\mathrm{BC}$. The peak in the evening is underestimated by about $0.1 \mu \mathrm{g} \mathrm{m}^{-3}$. Conversely, POA simulated in VBSMPOLI underestimates HOA on average by $-0.65 \mu \mathrm{g} \mathrm{m}{ }^{-3}$ $(-70 \%)$, corresponding to lower OA emissions.

The observed POA / BC ratio at LHVP is 0.34, while the predicted one is 1.21 , and thus largely overestimated, in the CSS simulation. It is reduced to about 0.27 in VBS-T1 and VBS-T2. This indicates that it is important to take into account the POA volatility. However, the ratio is only 0.10 in VBS-MPOLI, thus nearly 3 times lower than observed. This indicates that large uncertainties still exist in the quantity of OA emissions and/or in their volatility distribution.

For instance, Cappa and Jimenez (2010) suggested that POA in Mexico City might be less volatile than indicated by the volatility profile of Robinson et al. (2007). When implementing their revised volatility profile into the VBS-T2 configuration, POA levels increased by $29 \%$ for a test period of several days during July 2009, which cannot explain the differences to the observations. Couvidat et al. (2012) proposed using increased POA emissions in order to take into account SVOC emissions, which might not be included in the emission inventory. However, at least for traffic emissions, which are obtained under low-dilution conditions, we think that the error due to unaccounted SVOC emissions should not exceed more than about $30 \%$ (see Sect. 3.3). Another hypothesis recently put forward is that OPOA might not be oxidized enough to be measured as part of the OOA fraction, but would appear as HOA (Aumont et al., 2012; Cappa and Wilson, 2012). In this case, the monthly average POA concentration from VBS-MPOLI would be close to the measured one with a negative bias of $-24 \%$, but the morning peak would still be missing (Fig. S7 in the Supplement).

Modeled SOA concentrations are underestimated on average by about $-0.73(-48 \%)$ and $-0.61 \mu \mathrm{g} \mathrm{m}^{-3}(-40 \%)$ from CSS and VBS-T1, respectively (Table S7 in the Supplement). The underestimation is larger during the polluted regimes R1, R2 and R3 than during R4 (Fig. 13). Conversely, during these regimes SOA is overestimated on average by $+0.79(52 \%)$ and $+0.61 \mu \mathrm{g} \mathrm{m}^{-3}(+37 \%)$ in VBST2 and VBS-MPOLI, respectively. The simulated SOA levels in VBS-T2 and VBS-MPOLI are similar to the observed OOA ones during R4. Contrary to the CSS and VBS-T1 simulations, all major peaks related to biogenic SOA during R3 are found in VBS-T2 and VBS-MPOLI. Modeled SOA is correlated with the OOA concentrations from 3-factor analysis with correlation coefficients of $0.66,0.76,0.87$, and 0.91 for CSS, VBS-T1, VBS-T2 and VBS-MPOLI simulations, respectively. The better correlation for VBS-T2 and VBSMPOLI indicates that it is important to take into account the chemical aging of secondary semi-volatile VOC products. Indeed, VBS-T2 and VBS-MPOLI, having a common simulation at the continental domain which gives the boundary condition of SOA to the nested regional domain, show similar time series. This highlights the important process of the chemical aging of secondary semi-volatile VOC products which forms SOA on a regional scale, affecting the Paris agglomeration especially during regimes of long-range transported pollution.

The observed average daily SOA variation is rather flat with a small afternoon peak. This flat diurnal variation indicates that advection of SOA from outside the agglomeration is responsible for the major part of SOA in the agglomeration (see also Freutel et al., 2013). The additional afternoon peak indicates additional locally formed SOA. This peak is more pronounced in VBS-T2 and VBS-MPOLI simulations. Conversely, in the CSS and VBS-T1 simulations, afternoon SOA values are even lower than the daily average.

Despite this encouraging comparison of VBS-T2 and VBS-MPOLI SOA simulations to OOA, SOA peak values are often overestimated by up to a factor of two during R1, R2 and R3 on 21 and 26 July (Fig. 12). This is in contradiction with simulation results reported for Mexico City which show a slight underestimation of the OOA levels (Hodzic et al., 2010) due to evaporation of freshly formed SOA with the Robinson et al. (2007) approach, which is likely too volatile as previously discussed. This could be related to the uncertainties in BVOC emissions in the MEGAN inventory, which often gives the highest biogenic emissions among European models (Langner et al., 2012) at a continental scale, 
though the predicted and observed biogenic VOC concentrations give good agreement in the Greater Paris region during the campaign (Fig. S4 in the Supplement). Another possible reason could be that the chemical aging may overestimate the SOA production after several days of transport, because of missing fragmentation processes in the VBS scheme, especially for biogenic VOC species (Fountoukis et al., 2011), though some reactions such as polymerization and oligomerization may increase SOA levels with high molecular weight compounds (Hallquist et al., 2009; Myriokefalitakis et al., 2011). As fragmentation becomes more important for oxidized SVOCs (Kroll et al., 2009; Donahue at al., 2012), this simplification affects in particular aged air masses. The chosen yields on the high end of available laboratory values may also contribute to the overestimation. Just like for sulfate, for $\mathrm{SOA}$ an $\mathrm{OH}$ overestimation would lead to an increased formation rate (Fig. S8 in the Supplement). Again, if OPOA was not oxidized enough to be measured as part of the OOA fraction, this would also lead to an overestimation of simulated SOA when compared to OOA. Excluding simulated OPOA from SOA would reduce this overestimation to only $10 \%$ for the VBS-MPOLI simulation (Fig. S7 in the Supplement).

\section{Conclusions}

CHIMERE simulations are performed and evaluated with observations obtained during the MEGAPOLI summer campaign. The VBS approach, which considers POA as semivolatile and accounts for gas phase chemical aging of semivolatile VOC, has been implemented into CHIMERE. Chemical aging of both anthropogenic and biogenic SVOC is taken into account in a configuration with both the standard LA inventory and the MPOLI inventory. This is the first evaluation of the VBS scheme for a European megacity.

The meteorological and pollutant species measurements allow the division of the summer campaign into four periods with different wind regimes and pollution levels: a continental polluted regime with important photochemical activity, a local regime with stagnant air masses, a regime with transport from Southern France and from Spain and with important photochemical activity, and an Atlantic regime during which Paris was affected by clean marine air masses. This variety of different regimes makes the results quite representative for general summer conditions over Western Europe, even if the Atlantic regime was overrepresented with respect to the climatologic average. Evaluation of meteorological parameters shows satisfactory results for temperature and wind. The simulated transition of the PBL height in the evening often takes place too early compared to the measurements, which is a well-known error for MM5 simulations.

Predicted $\mathrm{NO}_{\mathrm{x}}$ and $\mathrm{BC}$ show similar daily profiles with respect to the measurements, but they are generally overestimated. BC is overestimated by more than a factor of two when the LA inventory is used, while biases are re- duced when the MPOLI emission inventory is used. Ozone is well simulated with both emission inventories regardless of errors in $\mathrm{NO}_{\mathrm{x}}$; enhanced concentrations appear during the three low-wind and cloudless periods. Inorganic aerosol is mostly overestimated with respect to the measurements. Only a small local production of nitrate is predicted when the MPOLI inventory is used, in which agricultural ammonia emissions are reasonably distributed. Therefore, $\mathrm{NH}_{3}$ measurements will be an important issue in the future for further air quality model evaluation, in particular for the inorganic species. Sulfate peaks are sometimes overestimated during long-range transport periods, maybe due to errors in the chemical scheme or an overestimation of $\mathrm{OH}$ and possibly $\mathrm{H}_{2} \mathrm{O}_{2}$ on the European scale.

Both traffic-related simulated POA and HOA derived from a 3-factor PMF analysis of AMS measurements at the urban site show characteristic morning peaks. The simulated concentrations with the LA inventory substantially overestimate observations when POA is considered as non-volatile, while they are consistent with the measurements when applying the VBS approach. This indicates the importance of the volatility of POA in air quality simulations. However, using the MPOLI inventory together with the VBS scheme results in too low POA values. This could be either due to underestimated POA emissions in the Greater Paris region in this inventory or to an overestimated volatility. Further work on this subject is needed. If some OPOA was measured as part of HOA, the bias of simulation versus observation would be reduced. Cooking emissions, which need to be quantified in the further work, are not yet included in the emission inventories we used for simulations and could not be compared to observations.

Simulated SOA, defined as the sum of background OA, OPOA, ASOA and BSOA, is compared to the observed OOA. The SOA concentrations simulated with the singlestep scheme clearly underestimate OOA by a factor of around 5 , especially when aged air masses of rural origin are advected to the Paris region. While taking into account only the aged OPOA is still not enough to reproduce SOA peaks with important biogenic influence advected by southerly winds, taking into account the chemical aging of anthropogenic and biogenic SVOC greatly improves the comparison with measurements. In particular the SOA variability is correctly simulated, and all major peaks are represented. This is an important result, showing the capacity of the scheme to represent major SOA formation processes affecting a European megacity. However, the SOA concentrations are overestimated for peak values related to long-range transport of aged air masses to the agglomeration. This reflects uncertainties that still exist in emissions, yields and chemical aging of biogenic species, and the choice in this work of yields on the higher end of the range of available values. Another possible reason would be overestimated $\mathrm{OH}$ concentrations in the model. Including simulated OPOA within HOA and not in OOA would significantly reduce this overestimation. 
OA at LHVP is well simulated in VBS-T2 and VBSMPOLI, while CSS generally overestimates the morning peaks and VBS-T1 globally underestimates OA. The evening peak due to cooking activities is missing. Because of an important influence of transport from outside the domain on OA peak values during this campaign, OA levels for the peaks at GOLF, LHVP and SIRTA are relatively similar both in simulations and observations. All peaks during polluted-air periods (R1, R2 and R3) are reproduced only by the VBS-T2 and VBS-MPOLI configuration, including chemical aging of SVOC species.

Here, we presented a first evaluation study of the VBS scheme within the CHIMERE model for a European megacity, and demonstrated improved behavior as compared to a single-step scheme. A detailed comparison with the PMF based on high-resolution data (Crippa et al., 2013a) as well as combined AMS-PTRMS data (Crippa et al., 2013b) is currently in progress. Future studies will also investigate other periods of the year, like a winter episode, to get a more complete picture of representativeness and performance of the VBS approach throughout the year. During winter, larger biomass burning emissions and lower biogenic emissions are expected (Crippa et al., 2013c; Sciare et al., 2011; Healy et al., 2012). While this study addressed a model evaluation based on ground-based sites within the agglomeration, further studies will use airborne measurements that allow addressing the impact of Paris emissions on aerosol levels in the surroundings of the Paris agglomeration and the part of OA levels which are controlled by either biogenic or anthropogenic emissions.

\section{Supplementary material related to this article is available online at: http://www.atmos-chem-phys.net/13/ 5767/2013/acp-13-5767-2013-supplement.pdf.}

Acknowledgements. This research in the context of the MEGAPOLI project is financially supported by the European Community's Framework Program FP/2007-2011 under grant agreement no. 212520. Q. J. Zhang was supported by a PhD grant from the French CIFRE (ANRT) attributed to LISA and ARIA Technologies. Support from the French ANR project MEGAPOLI - PARIS (ANR-09-BLAN-0356), from the French ADEME via the CNRS-INSU/FEFE program and the Ile de France/SEPPE as well as from internal Max Planck Institute for Chemistry funds are acknowledged. We are very grateful for strong logistical support in the field by IPSL/SIRTA, by Laboratoire d'Hygiène de la Ville de Paris (LHVP) and by the staff of the Golf de la Poudrerie. In addition, we thank the teams of participating laboratories for support during the campaign.

Edited by: A. Baklanov

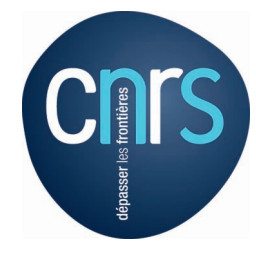

The publication of this article is financed by CNRS-INSU.

\section{References}

Airparif: Inventaire des emissions en Ile De France, Méthodolgie et Résultats, Avril 2010, 2010.

Aumont, B., Valorso, R., Mouchel-Vallon, C., Camredon, M., LeeTaylor, J., and Madronich, S.: Modeling SOA formation from the oxidation of intermediate volatility $n$-alkanes, Atmos. Chem. Phys., 12, 7577-7589, doi:10.5194/acp-12-7577-2012, 2012.

Baklanov, A., Lawrence, M. G. and Pandis, S. N.: Description of work document for the European Collaborative Project "Megacities: Emissions, urban, regional and Global Atmospheric POLlution and climate effects, and Integrated tools for assessment and mitigation" (MEGAPOLI) for the Seventh Framework Programme of the European Commission, http://meagpoli.info, 2008.

Beekmann, M., Kerschbaumer, A., Reimer, E., Stern, R., and Möller, D.: PM measurement campaign HOVERT in the Greater Berlin area: model evaluation with chemically specified particulate matter observations for a one year period, Atmos. Chem. Phys., 7, 55-68, doi:10.5194/acp-7-55-2007, 2007.

Beekmann, M. and Vautard, R.: A modelling study of photochemical regimes over Europe: robustness and variability, Atmos. Chem. Phys., 10, 10067-10084, doi:10.5194/acp-1010067-2010, 2010.

Bergström, R., Denier van der Gon, H. A. C., Prévôt, A. S. H., Yttri, K. E., and Simpson, D.: Modelling of organic aerosols over Europe (2002-2007) using a volatility basis set (VBS) framework: application of different assumptions regarding the formation of secondary organic aerosol, Atmos. Chem. Phys., 12, 8499-8527, doi:10.5194/acp-12-8499-2012, 2012.

Bessagnet, B., Menut, L., Curci, G., Hodzic, A., Guillaume, B., Liousse, C., Moukhtar, S., Pun, B., Seigneur, C., and Schulz, M.: Regional modeling of carbonaceous aerosols over Europe - focus on secondary organic aerosols, J. Atmos. Chem., 61, 175-202, 2009.

Cabada, J. C., Pandis, S. N., Subramanian, R., Robinson, A. L., Polidori, A., and Turpin, B.: Estimating the Secondary Organic Aerosol Contribution to $\mathrm{PM}_{2.5}$ Using the EC Tracer Method, Aerosol Sci. Technol., 38, 140-155, 2004.

Cachier H., Buat-Ménard P., Fontugne M., and Chesselet R.: Longrange transport of continentally-derived particulate carbon in the marine atmosphere: evidence from stable carbon isotope studies, Tellus B - Chem. Phys. Meteorol., 38, 161-177, 1986.

Cappa, C. D. and Jimenez, J. L.: Quantitative estimates of the volatility of ambient organic aerosol Atmos. Chem. Phys., 10, 5409-5424, doi:10.5194/acp-10-5409-2010, 2010.

Cappa, C. D. and Wilson, K. R.: Multi-generation gas-phase oxidation, equilibrium partitioning, and the formation and evolution of secondary organic aerosol, Atmos. Chem. Phys., 12, 9505-9528, doi:10.5194/acp-12-9505-2012, 2012.

Carter, W. P. L.: SAPRC-99 mechanism files and associated programs and examples, www.engr.ucr.edu/ carter/SAPRC99/, 
2000.

CITEPA: Air emissions in France, Substances causing acidification, eutrophication and photochemical Pollution, Centre Interprofessionnel Technique d'Etudes de la Pollution Atmospherique, Paris, 2010.

Couvidat, F., Édouard Debry, E., Sartelet, K., and Christian Seigneur, C.: A hydrophilic/ hydrophobic organic $\left(\mathrm{H}_{2} \mathrm{O}\right)$ aerosol model: Development, evaluation and sensitivity analysis, J. Geophys. Res., 117, D10304, doi:10.1029/2011JD017214, 2012.

Couvidat, F., Kim, Y., Sartelet, K., Seigneur, C., Marchand, N., and Sciare, J.: Modeling secondary organic aerosol in an urban area: application to Paris, France, Atmos. Chem. Phys., 13, 983-996, doi:10.5194/acp-13-983-2013, 2013.

Crippa, M., El Haddad, I., Slowik, J. G., DeCarlo, P. F., Mohr, C., Heringa, M. F., Chirico, R., Marchand, N., Jean, S., Baltensperger, U., Prévôt, A. S. H.: Identification of marine and continental aerosol sources in Paris using high resolution aerosol mass spectrometry, J. Geophys. Res. 118, 1-19, doi:10.1002/jgrd.50151, 2013a.

Crippa, M., Canonaco, F., Slowik, J. G., El Haddad, I., DeCarlo, P. F., Mohr, C., Heringa, M. F., Chirico, R., Marchand, N., Temime-Roussel, B., Abidi, E., Poulain, L., Wiedensohler, A., Baltensperger, U., and Prévôt, A. S. H.: Primary and secondary organic aerosol origin by combined gas-particle phase source apportionment, Atmos. Chem. Phys. Discuss., 13, 8537-8583, doi:10.5194/acpd-13-8537-2013, 2013 b.

Crippa, M., DeCarlo, P. F., Slowik, J. G., Mohr, C., Heringa, M. F., Chirico, R., Poulain, L., Freutel, F., Sciare, J., Cozic, J., Di Marco, C. F., Elsasser, M., José, N., Marchand, N., Abidi, E., Wiedensohler, A., Drewnick, F., Schneider, J., Borrmann, S., Nemitz, E., Zimmermann, R., Jaffrezo, J.-L., Prévôt, A. S. H., and Baltensperger, U.: Wintertime aerosol chemical composition and source apportionment of the organic fraction in the metropolitan area of Paris, Atmos. Chem. Phys., 13, 961-981, doi:10.5194/acp-13-961-2013, 2013c

DeCarlo, P. F., Kimmel, J. R., Trimborn, A., Northway, M. J., Jayne, J. T., Aiken, A. C., Gonin, M., Fuhrer, K., Horvath, T., Docherty, K. S., Worsnop, D. R., and Jimenez, J. L.: Field-deployable, high-resolution, time-of-flight aerosol mass spectrometer, Anal. Chem., 78, 8281-8289, 2006.

Denier van der Gon, H. A. C., Beevers, S., D’Allura, Al., Finardi, S., Honoré, C., Kuenen, J., Perrussel, O., Radice, P., Theloke, J., Uzbasich, M., and Visschedijk, A.: Discrepancies Between TopDown and Bottom-Up Emission Inventories of Megacities: The Causes and Relevance for Modeling Concentrations and Exposure, edited by: Steyn, D. G. and Castelli, S. T., NATO Science for Peace and Security Series C: Environmental Security, Vol. 4, Springer, ISBN 978-94-007-1358-1 772 pp., 2011.

Derognat, C., Beekmann, M., Baeumle, M., Martin, D., and Schmidt, H.: Effect of biogenic volatile organic compound emissions on tropospheric chemistry during the atmospheric Pollution Over the Paris Area (ESQUIF) campaign in the Ile-de-France region. J. Geophys. Res., 108, 8560, doi:10.1029/2001JD001421, 2003.

Donahue, N. M., Robinson, A. L., Stanier, C. O., and Pandis, S. N.: Coupled partitioning, dilution, and chemical aging of semivolatile organics, Environ. Sci. Technol., 40, 2635-2643, 2006.

Donahue, N. M., Henry, K. M., Mentel, T. F., Kiendler-Scharr, A., Spindler, C., Bohn, B., Brauers, T., Dorn, H. P., Fuchs, H., Till- mann, R., Wahner, A., Saathoff, H., Naumann, K.-H., Moehler, O., Leisner, T., Mueller, L., Reinnig, M.-C., Hoffmann, T., Salo, K., Hallquist, M., Frosch, M., Bilde, M., Tritscher, T., Barmet, P., Praplan, A. P., DeCarlo, P. F., Dommen, J., Prévôt, A. S. H., and Baltensperger, U.: Aging of secondary organic aerosol: connecting chambers to the atmosphere, Proc. Natl. Acad. Sci. USA, 109, 13503-13508, 2012.

Drewnick, F., Hings, S. S., DeCarlo, P., Jayne, J. T., Gonin, M., Fuhrer, K., Weimer, S., Jimenez, J. L., Demerjian, K. L., Borrmann, S., and Worsnop, D. R.: A new time-of-flight aerosol mass spectrometer (TOF-AMS) - Instrument description and first field deployment, Aerosol Sci. Technol., 39, 637-658, 2005.

Dudhia, J.: A nonhydrostatic version of the Penn State/NCAR mesoscale model: validation tests and simulation of an Atlantic cyclone and cold front, Mon. Weather Rev., 121, 1493-1513, 1993.

Fast, J., Aiken, A. C., Allan, J., Alexander, L., Campos, T., Canagaratna, M. R., Chapman, E., DeCarlo, P. F., de Foy, B., Gaffney, J., de Gouw, J., Doran, J. C., Emmons, L., Hodzic, A., Herndon, S. C., Huey, G., Jayne, J. T., Jimenez, J. L., Kleinman, L., Kuster, W., Marley, N., Russell, L., Ochoa, C., Onasch, T. B., Pekour, M., Song, C., Ulbrich, I. M., Warneke, C., Welsh- Bon, D., Wiedinmyer, C., Worsnop, D. R., Yu, X. Y., and Zaveri, R.: Evaluating simulated primary anthropogenic and biomass burning organic aerosols during MILAGRO: implications for assessing treatments of secondary organic aerosols, Atmos. Chem. Phys., 9, 6191-6215, doi:10.5194/acp-9-6191-2009, 2009.

Friedrich, R.: GENEMIS: assessment, improvement, temporal and spatial disaggregation of European emission data, in: Tropospheric Modelling and Emission Estimation, Part 2, edited by: Ebel, A., Friedrich, R., and Rhode, H., Springer, New York, 181214, 1997.

Freutel, F., Schneider, J., Drewnick, F., Von der WeidenReinmüller, S.-L., Crippa, M., Prévôt, A. S. H., Baltensperger, U., Poulain, L., Wiedensohler, A., Sciare, J., SardaEstève, R., Burkhart, J. F., Eckhardt, S., Stohl, A., Gros, V., Colomb, A., Michoud, V., Doussin, J. F., Borbon, A., Haeffelin, M., Morille, Y., Beekmann, M., and Borrmann, S.: Aerosol particle measurements at three stationary sites in the megacity of Paris during summer 2009: meteorology and air mass origin dominate aerosol particle composition and size distribution, Atmos. Chem. Phys., 13, 933-959, doi:10.5194/acp-13-933-2013, 2013.

Fountoukis, C., Racherla, P. N., Denier van der Gon, H. A. C., Polymeneas, P., Charalampidis, P. E., Pilinis, C., Wiedensohler, A., Dall'Osto, M., O'Dowd, C., and Pandis, S. N.: Evaluation of a three-dimensional chemical transport model (PMCAMx) in the European domain during the EUCAARI May 2008 campaign, Atmos. Chem. Phys., 11, 10331-10347, doi:10.5194/acp11-10331-2011, 2011.

Grieshop, A. P., Logue, J. M., Donahue, N. M., and Robinson, A. L.: Laboratory investigation of photochemical oxidation of organic aerosol from wood fires 1: Measurement and simulation of organic aerosol evolution, Atmos. Chem. Phys., 9, 1263-1277, doi:10.5194/acp-9-1263-2009, 2009.

Guenther, A., Karl, T., Harley, P., Wiedinmyer, C., Palmer, P. I., and Geron, C.: Estimates of global terrestrial isoprene emissions using MEGAN (Model of Emissions of Gases and Aerosols from Nature), Atmos. Chem. Phys., 6, 3181-3210, doi:10.5194/acp-6- 
3181-2006, 2006.

Gurjar, B. R., Butler, T. M., Lawrence, M. G., and Lelieveld, J.: Evaluation of emissions and air quality in megacities, Atmos. Environ., 42, 1593-1606, 2008.

Haeffelin, M., Angelini, F., Morille, Y., Martucci, G., Frey, S., Gobbi, G.-P., Lolli, S., O’Dowd, C. D., Sauvage, L., XuerefRémy, I., Wastine, B., and Feist, D.: Evaluation of mixing height retrievals from automatic profiling lidars and ceilometers in view of future integrated networks in Europe, Bound.-Layer. Meteorol., 143, 49-75, 2012.

Haeffelin, M., Barthés, L., Bock, O., Boitel, C., Bony, S., Bouniol, D., Chepfer, H., Chiriaco, M., Cuesta, J., Delanoë, J., Drobinski, P., Dufresne, J.-L., Flamant, C., Grall, M., Hodzic, A., Hourdin, F., Lapouge, F., Lemaître, Y., Mathieu, A., Morille, Y., Naud, C., Noël, V., O'Hirok, W., Pelon, J., Pietras, C., Protat, A., Romand, B., Scialom, G., and Vautard, R.: SIRTA, a ground-based atmospheric observatory for cloud and aerosol research, Ann. Geophys., 23, 253-275, doi:10.5194/angeo-23-253-2005, 2005.

Hallquist, M., Wenger, J. C., Baltensperger, U., Rudich, Y., Simpson, D., Claeys, M., Dommen, J., Donahue, N. M., George,C., Goldstein, A. H., Hamilton, J. F., Herrmann, H., Hoffmann, T., Iinuma, Y., Jang, M., Jenkin, M. E., Jimenez, J. L.,KiendlerScharr, A., Maenhaut, W., McFiggans, G., Mentel, Th. F., Monod, A., Prévôt, A. S. H., Seinfeld, J. H., Surratt, J. D., Szmigielski, R., and Wildt, J.: The formation, properties and impact of secondary organic aerosol: current and emerging issues, Atmos. Chem. Phys., 9, 5155-5236, doi:10.5194/acp-9-51552009, 2009.

Hauglustaine, D. A., Hourdin, F., Jourdain, L., Filiberti, M.A., Walters, S., Lamarque, J.-F., and Holland, E. A.: Interactive chemistry in the Laboratoire de Meteorologie. Dynamique general circulation model: Description and background tropospheric chemistry evaluation, J. Geophys. Res., 109, D04314, doi:10.1029/2003JD003957, 2012.

Healy, R. M., Sciare, J., Poulain, L., Kamili, K., Merkel, M., Müller, T., Wiedensohler, A., Eckhardt, S., Stohl, A., Sarda-Estève, R., McGillicuddy, E., O'Connor, I. P., Sodeau, J. R., and Wenger, J. C.: Sources and mixing state of size-resolved elemental carbon particles in a European megacity: Paris, Atmos. Chem. Phys., 12, 1681-1700, doi:10.5194/acp-12-1681-2012, 2012.

Hildebrandt, L., Donahue, N. M., and Pandis, S. N.: High formation of secondary organic aerosol from the photo-oxidation of toluene, Atmos. Chem. Phys., 9, 2973-2986, doi:10.5194/acp-92973-2009, 2009.

Hodzic, A., Jimenez, J. L., Madronich, S., Aiken, A. C., Bessagnet,B., Curci, G., Fast, J., Lamarque, J.-F., Onasch, T. B., Roux,G., Schauer, J. J., Stone, E. A., and Ulbrich, I. M.: Modelingorganic aerosols during MILAGRO: importance of biogenic secondary organic aerosols, Atmos. Chem. Phys., 9, 6949-6981, doi:10.5194/acp-9-6949-2009, 2009.

Hodzic, A., Jimenez, J. L., Madronich, S., Canagaratna, M. R., DeCarlo, P. F., Kleinman, L., and Fast, J.: Modeling organic aerosols in a megacity: potential contribution of semi-volatile and intermediate volatility primary organic compounds to secondary organic aerosol formation, Atmos. Chem. Phys., 10, 5491-5514, doi:10.5194/acp-10-5491-2010, 2010.

Hong, S. Y. and Pan, H. L.: Nonlocal boundary layer vertical diffusion in a Medium-Range Forecast model, Mon. Weather Rev., 124, 2322-2339, 1996.
Honoré, C. , Rouil, L., Vautard, R., Beekmann, M., Bessagnet, B., Dufour, A., Elichegaray, C., Flaud, J.-M., Malherbe, L., Meleux, F., Menut, L., Martin, D., Peuch, A., Peuch, V. H., and Poisson, N.: Predictability of European air quality: The assessment of three years of operational forecasts and analyses by the PREV'AIR system, J. Geophys. Res., 113, D04301, doi:10.1029/2007JD008761, 2008.

IPCC: Forster, P., Ramaswamy, V., Artaxo, P., Berntsen, T., Betts, R., Fahey, D. W., Haywood, J., Lean, J., Lowe, D. C., Myhre, G., Nganga, J., Prinn, R., Raga, G., Schulz, M., and Van Dorland, R.: Changes in Atmospheric Constituents and in Radiative Forcing, in: Climate Change 2007: The Physical Science Basis. Contribution of Working Group I to the Fourth Assessment Report of the Intergovernmental Panel on Climate Change, edited by: Solomon, S., Qin, D., Manning, M., Chen, Z., Marquis, M., Averyt, K. B., Tignor, M., and Miller, H. L., Cambridge University Press, Cambridge, UK and New York, NY, USA, 2007.

Junker, C. and Liousse, C.: A global emission inventory of carbonaceous aerosol from historic records of fossil fuel and biofuel consumption for the period 1860-1997, Atmos. Chem. Phys., 8, 1195-1207, doi:10.5194/acp-8-1195-2008, 2008.

Kroll, J. H. and Seinfeld, J. H.: Chemistry of secondary organic aerosol: Formation and evolution of low-volatility organics in the atmosphere, Atmos. Environ., 42, 3593-3624, 2008.

Kroll, J. H., Smith, J. D., Che, D. L., Kessler, S. H., Worsnop, D. R., and Wilson, K. R.: Measurement of fragmentation and functionalization pathways in the heterogeneous oxidation of oxidized organic aerosol, Phys. Chem. Chem. Phys., 11, 8005-8014, 2009.

Kukkonen, J., Olsson, T., Schultz, D. M., Baklanov, A., Klein, T., Miranda, A. I., Monteiro, A., Hirtl, M., Tarvainen, V., Boy, M., Peuch, V.-H., Poupkou, A., Kioutsioukis, I., Finardi, S., Sofiev, M., Sokhi, R., Lehtinen, K. E. J., Karatzas, K., San José, R., Astitha, M., Kallos, G., Schaap, M., Reimer, E., Jakobs, H., and Eben, K.: A review of operational, regional-scale, chemical weather forecasting models in Europe, Atmos. Chem. Phys., 12, 1-87, doi:10.5194/acp-12-1-2012, 2012.

Lane, T. E., Donahue, N. M., and Pandis, S. N.: Simulating secondary organic aerosol formation using the volatility basis-set approach in a chemical transport model, Atmos. Environ., 42, 7439-7451, 2008a.

Lane, T. E., Donahue, N. M., and Pandis, S. N.: Effect of $\mathrm{NO}_{\mathrm{x}}$ on secondary organic aerosol concentrations, Environ. Sci. Technol., 42, 6022-6027, 2008b.

Langner, J., Engardt, M., Baklanov, A., Christensen, J. H., Gauss, M., Geels, C., Hedegaard, G. B., Nuterman, R., Simpson, D., Soares, J., Sofiev, M., Wind, P., and Zakey, A.: A multi-model study of impacts of climate change on surface ozone in Europe, Atmos. Chem. Phys., 12, 10423-10440, doi:10.5194/acp12-10423-2012, 2012.

Lanz, V. A., Prévôt, A. S. H., Alfarra, M. R., Weimer, S., Mohr, C., DeCarlo, P. F., Gianini, M. F. D., Hueglin, C., Schneider, J., Favez, O., D’Anna, B., George, C., and Baltensperger, U.: Characterization of aerosol chemical composition with aerosol mass spectrometry in Central Europe: an overview, Atmos. Chem. Phys., 10, 10453-10471, doi:10.5194/acp-10-10453-2010, 2010.

Lattuati, M.: Contribution à l'étude du bilan de l'ozone troposphérique à l'interface de l'Europe et de l'Atlantique Nord: modélisation lagrangienne et mesures en altitude. Thèse de sciences, Université Paris 6, France, 1997. 
Loosmore, G. and Cederwall, R.: Precipitation scavenging of atmospheric aerosols for emergency response applications: testing an updated model with new real-time data. Atmos. Env., 38, 9931003, 2004.

Michoud, V., Kukui, A., Camredon, M., Colomb, A., Borbon, A., Miet, K., Aumont, B., Beekmann, M., Durand-Jolibois, R., Perrier, S., Zapf, P., Siour, G., Ait-Helal, W., Locoge, N., Sauvage, S., Gros, V., Afif, C., Furger, M., Ancellet, G., and Doussin, J. F.: Radical budget analysis in a suburban European site during the MEGAPOLI summer field campaign, Atmos. Chem. Phys., 12, 11951-11974, doi:10.5194/acp-12-11951-2012, 2012.

Middleton, P., Stockwell, W. R., and Carter, W. P.: Agregation and analysis of volatile organic compound emissions for regional modelling, Atmos. Environ., 24, 1107-1133, 1990.

Mohr, C., DeCarlo, P. F., Heringa, M. F., Chirico, R., Slowik, J. G., Richter, R., Reche, C., Alastuey, A., Querol, X., Seco, R., Peñuelas, J., Jiménez, J. L., Crippa, M., Zimmermann, R., Baltensperger, U., and Prévôt, A. S. H.: Identification and quantification of organic aerosol from cooking and other sources in Barcelona using aerosol mass spectrometer data. Atmos. Chem. Phys. 12, 1649-1665, doi:10.5194/acp-12-1649-2012, 2012.

Molina, M. J. and Molina, L. T.: Critical review: mega cities and atmospheric pollution, J. Air Waste Manage Assoc., 54, 644-680, 2004.

Murphy, B. N. and Pandis, S. N.: Simulating the formation of semivolatile primary and secondary organic aerosol in a regional chemical transport model, Environ. Sci. Technol., 43, 47224728, 2009.

Myriokefalitakis, S., Tsigaridis, K., Mihalopoulos, N., Sciare, J., Nenes, A., Kawamura, K., Segers, A., and Kanakidou, M.: Atmos. Chem. Phys., 11, 5761-5782, doi:10.5194/acp-11-57612011, 2011.

Nenes, A., Pilinis, C., and Pandis, S.: ISORROPIA: A new thermodynamic model for inorganic multicomponent atmospheric aerosols, Aquat. Geochem., 4, 123-152, 1998.

Ng, N. L., Kroll, J. H., Keywood, M. D., Bahreini, R., Varutbangkul, V., Flagan, R. C., Seinfeld, J. H., Lee, A., and Goldstein, A. H.,: Contribution of first- versus second-generation products to secondary organic aerosols formed in the oxidation of biogenic hydrocarbons, Environ. Sci. Technol., 40, 2283-2297, 2006.

Ng, N. L., Kroll, J. H., Chan, A. W. H., Chhabra, P. S., Flagan, R. C., and Seinfeld, J. H.: Secondary organic aerosol formation from m-xylene, toluene, and benzene, Atmos. Chem. Phys., 7, 3909-3922, doi:10.5194/acp-7-3909-2007, 2007a.

Ng, N. L., Chhabra, P. S., Chan, A. W. H., Surratt, J. D., Kroll, J. H., Kwan, A. J., McCabe, D. C., Wennberg, P. O., Sorooshian, A., Murphy, S. M., Dalleska, N. F., Flagan, R. C., and Seinfeld, J. H.: Effect of $\mathrm{NO}_{\mathrm{x}}$ level on secondary organic aerosol (SOA) formation from the photooxidation of terpenes, Atmos. Chem. Phys., 7, 5159-5174, doi:10.5194/acp-7-5159-2007, 2007b.

Oladoyin Salako, G. O., Hopke, P. K., Cohen, D. D., Begum, B. A., Biswas, S. K., Girish Pandit, G., Yong-Sam Chung, Abd Rahman, S., Suhaimi Hamzah, M., Davy, P., Markwitz, A., Shagjjamba, D., Lodoysamba, S., Wimolwattanapun W., Bunprapob S.: Exploring the variation between $\mathrm{EC}$ and $\mathrm{BC}$ in a variety of locations, Aerosol Air Qual. Res., 12: 1-7, 2012.

Pankow, J.: An absorption model of the gas/aerosol partitioning involved in the formation of secondary organic aerosol, Atmos. Environ., 28, 189-193, 1994.
Passant, N. R.: Speciation of U.K. emissions of non-methane VOC, AEAT/ENV/0545 Issue 1, 2002.

Pillot, D., Darmon, A., Besombes, A., Cazier, J. L., Hanoune, F., Vidon, R., Perret, P., and Tassel, P.: Émissions de polluants de 10 véhicules légers alimentés en biocarburants à différentes teneurs et GNV - Rapport final. Rapport INRETS-LTE Nº905 INRETS, Bron, France. 89 pp., edited by: André, M., Joumard, R., Clairet, J. M., 2008. (translation in English: Pollutant emissions of ten light vehicles working with different fractions of biofuels and natural gas), http://www.inrets.fr/ur/lte/publications/ publipollu.html, 2009.

Pouliot, G., Pierce, T, Denier van der Gon, H., Schaap, M., and Nopmongcol, U.: Comparing Emissions Inventories and ModelReady Emissions Datasets between Europe and North America for the AQMEII Project, Atmos. Environ., (AQMEII issue), 53, 4-14, 2012.

Presto, A. A., Miracolo, M. A., Kroll, J. H., Worsnop, D. R., Robinson, A. L., and Donahue, N. M.: Intermediate-volatility organic compounds: A potential source of ambient oxidized organic aerosol, Environ. Sci. Technol., 43, 4744-4749, 2009.

Presto, A. A., Miracolo, M. A., Donahue, N. M., and Robinson, A. L.: Secondary organic aerosol formation from high- $\mathrm{NO}_{\mathrm{x}}$ photooxidation of low volatility precursors: n-Alkanes, Environ. Sci. Technol., 44, 2029-2034, 2010.

Pun, B. K., Seigneur, C., and Lohman, K.: Modeling secondary organic aerosol formation via multiphase partitioning with molecular data, Environ. Sci. Technol., 40, 4722-4731, 2006.

Putaud, J.-P., Van Dingenen, R., Alastuey, A., Bauer, H., Birmili, W., Cyrys, J., Flentje, H., Fuzzi, S., Gehrig, R., Hansson, H. C., Harrison, R. M., Herrmann, H., Hitzenberger, R. , Hüglin, C., Jones, A. M., Kasper-Giebl, A., Kiss, G., Kousa, A., Kuhlbusch, T. A. J., Löschau, G., Maenhaut, W., Molnar, A., Moreno, T., Pekkanen, J., Perrino, C., Pitz, M., Puxbaum, H., Querol, X., Rodriguez, S., Salma, I., Schwarz, J., Smolik, J., Schneider, J., Spindler, G., ten Brink, H., Tursic, J., Viana, M., Wiedensohler, A., and Raes, F.: A European aerosol phenomenology - 3: Physical and chemical characteristics of particulate matter from 60 rural, urban, and kerbside sites across Europe, Atmos. Env., 44, 1308-1320, 2010.

Robinson, A. L., Donahue, N. M., Shrivastava, M. K., Weitkamp, E. A., Sage, A. M., Grieshop, A. P., Lane, T. E., Pierce, J. R., and Pandis, S. N.: Rethinking organic aerosols: Semi-volatile emissions and photochemical aging, Science, 315, 1259-1262, 2007.

Royer P., Chazette P., Sartelet K., Zhang Q. J., Beekmann M., and Raut J.-C.: Comparison of lidar-derived $\mathrm{PM}_{10}$ with regional modeling and ground-based observations in the frame of MEGAPOLI experiment, Atmos. Chem. Phys., 11, 1070510726, doi:10.5194/acp-11-10705-2011, 2011.

Sciare, J., d'Argouges, O., Zhang, Q. J., Sarda-Estève, R., Gaimoz, C., Gros, V., Beekmann, M., and Sanchez, O.: Comparison between simulated and observed chemical composition of fine aerosols in Paris (France) during springtime: contribution of regional versus continental emissions, Atmos. Chem. Phys., 10, 11987-12004, doi:10.5194/acp-1-11987-2010, 2010.

Sciare, J., d'Argouges, O., Sarda-Esteve, R., Gaimoz, C., Dolgorouky, C., Bonnaire, N., Favez, O., Bonsang, B., and Gros, V.: Large contribution of water-insoluble secondary organic aerosols in the region of Paris (France) during wintertime, J. Geophys. Res. Atmos., 116, D22203, doi:10.1029/2011JD015756, 2011. 
Seinfeld, J. H. and Pandis, S. N.: Atmospheric Chemistry and Physics: From Air Pollution to Climate Change, John Wiley, Hoboken, NJ, USA, 350-434, 2006.

Shrivastava, M. K., Lane, T. E., Donahue, N. M., Pandis, S. N., and Robinson, A. L.: Effects of gas particle partitioning and aging of primary emissions on urban and regional organic aerosol concentrations, J. Geophys. Res., 113, D18301, doi:10.1029/2007JD009735, 2008.

Shrivastava, M., Fast, J., Easter, R., Gustafson Jr., W. I., Zaveri, R. A., Jimenez, J. L., Saide, P., and Hodzic, A.: Modeling organic aerosols in a megacity: comparison of simple and complex representations of the volatility basis set approach, Atmos. Chem. Phys., 11, 6639-6662, doi:10.5194/acp-11-6639-2011, 2011.

Sicard, P., Mangin, A., Hebel, P., and Mallea, P.: Detection and estimation trends linked to air quality and mortality on French Riviera over the 1990-2005 period. Sci. Total Environ., 408, 19431950, 2011.

Simpson, D., Yttri, K., Klimont, Z., Kupiainen, K., Caseiro, A., Gelencsér, A., Pio, C., and Legrand, M.: Modeling carbonaceous aerosol over Europe. Analysis of the CARBOSOL and EMEP EC/OC campaigns, J. Geophys. Res., 112, D23S14, doi:10.1029/2006JD008158, 2007.

Strader, R., Lurmann, F., and Pandis, S. N.: Evaluation of secondary organic aerosol formation in winter, Atmos. Environ., 33, 48494863, 1999.

Tsimpidi, A. P., Karydis, V. A., Zavala, M., Lei, W., Molina, L., Ulbrich, I. M., Jimenez, J. L., and Pandis, S. N.: Evaluation of the volatility basis-set approach for the simulation of organic aerosol formation in the Mexico City metropolitan area, Atmos. Chem. Phys., 10, 525-546, doi:10.5194/acp-10-525-2010, 2010.

Tsyro, S.. First estimates of the effect of aerosol dynamics in the calculation of $\mathrm{PM}_{10}$ and $\mathrm{PM}_{2.5}$, EMEP report, 2002.

Turpin, B. J. and Huntzicker, J. J.: Identification of secondary organic aerosol episodes and quantification of primary and secondary organic aerosol concentrations during SCAQS, Atmos. Environ., 29, 3527-3544, 1995.

Ulbrich, I. M., Canagaratna, M. R., Zhang, Q., Worsnop, D. R., and Jimenez, J. L.: Interpretation of organic components from positive matrix factorization of aerosol mass spectrometric data, Atmos. Chem. Phys., 9, 2891-2918, doi:10.5194/acp-9-2891-2009, 2009.
Vaden, T. D., Song, C., Zaveri, R. A., Imre, D., and Zelenyuk, A.: Morphology of mixed primary and secondary organic particles and the adsorption of spectator organic gases during aerosol formation, Proc. Natl. Acad. Sci. USA, 107, 6658-6663, doi:10.1073/pnas.0911206107, 2010.

Vaden, T. D., Imre, D., Beranek, J., Shrivastava, M., and Zelenyuk, A.: Evaporation kinetics and phase of laboratory and ambient secondary organic aerosol, Proc. Natl. Acad. Sci. USA, 21902195, doi:10.1073/pnas.1013391108, 2011.

Valorso, R., Aumont, B., Camredon, M., Raventos-Duran, T., Mouchel-Vallon, C., Ng, N. L., Seinfeld, J. H., Lee-Taylor, J., and Madronich, S.: Explicit modelling of SOA formation from $\alpha$-pinene photooxidation: sensitivity to vapour pressure estimation, Atmos. Chem. Phys., 11, 6895-6910, doi:10.5194/acp-116895-2011, 2011.

Virtanen, A., Joutsensaari, J., Koop, T., Kannosto, J., Yli-Pirila, P., Leskinen, J., Makela, J. M., Holopainen, J. K., Pöschl, U., Kulmala, M., Worsnop, D. R., and Laaksonen, A.: An amorphous solid state of biogenic secondary organic aerosol particles, Nature, 467, 824-827, doi:10.1038/nature09455, 2010.

Volkamer, R., Jimenez, J. L., Martini, F. S., Dzepina, K., Zhang, Q., Salcedo, D., Molina, L. T., Worsnop, D. R., and Molina, M. J.: Secondary organic aerosol formation from anthropogenic air pollution: Rapid and higher than expected, Geophys. Res. Lett., 33, L17811, doi:10.1029/2006GL026899, 2006.

Wesely, M.: Parameterization of surface resistances to gaseous dry deposition in regional-scale numerical models, Atmos. Environ., (23):1293-1304, 1989

Zhang, Q. J., Laurent, B., Velay-Lasry, F., Ngo, R., Derognat, C., Marticorena, B., Albergel, A.: An air quality forecasting system in Beijing - Application to the study of dust storm events in China in May 2008, J. Environ. Sci., 24, 102-111, doi:10.1016/S1001-0742(11)60733-X, 2012. 